University of New Hampshire

University of New Hampshire Scholars' Repository

DNP Scholarly Projects

Student Scholarship

Spring 2018

\title{
The evaluation of a breast cancer screening decision aid in the community setting.
}

Kimberly Gibbons

University of New Hampshire, Durham

Follow this and additional works at: https://scholars.unh.edu/scholarly_projects

Part of the Nursing Midwifery Commons, and the Other Nursing Commons

\section{Recommended Citation}

Gibbons, Kimberly, "The evaluation of a breast cancer screening decision aid in the community setting." (2018). DNP Scholarly Projects. 3.

https://scholars.unh.edu/scholarly_projects/3

This Clinical Doctorate is brought to you for free and open access by the Student Scholarship at University of New Hampshire Scholars' Repository. It has been accepted for inclusion in DNP Scholarly Projects by an authorized administrator of University of New Hampshire Scholars' Repository. For more information, please contact Scholarly.Communication@unh.edu. 
The evaluation of a breast cancer screening decision aid in the community setting.

\title{
Kimberly Cuetara Gibbons
}

University of New Hampshire

\begin{abstract}
Author notes
This project was completed in partial fulfillment of the requirements of the Doctor of Nursing Practice program at the University of New Hampshire.

Correspondence concerning this project and or report should be directed to Kimberly.Gibbons1@gmail.com
\end{abstract}


BREAST CANCER SCREENING DECISION AID

Table of Contents

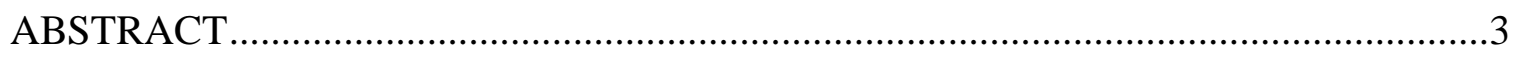

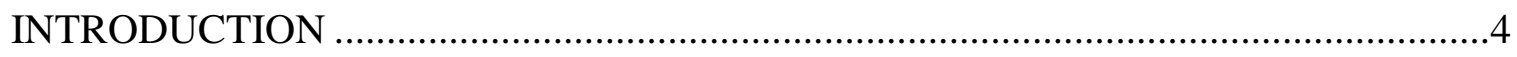

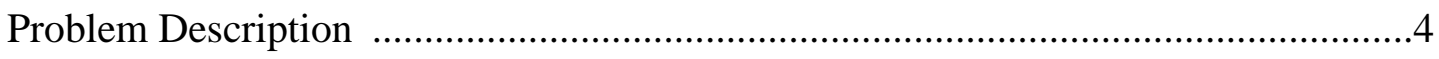

Available Knowledge...................................................................................

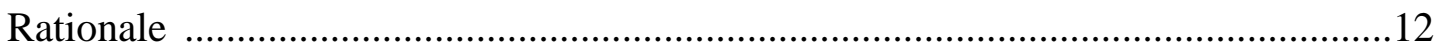

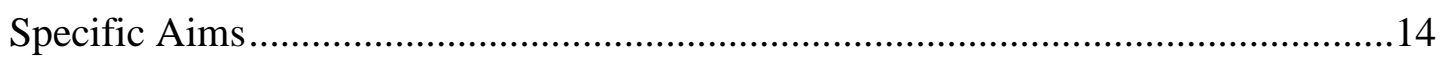

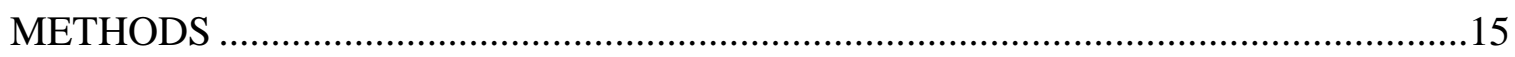

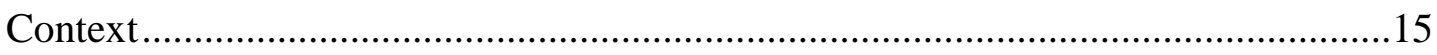

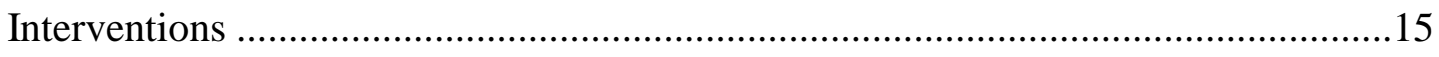

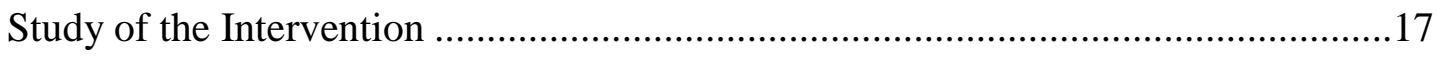

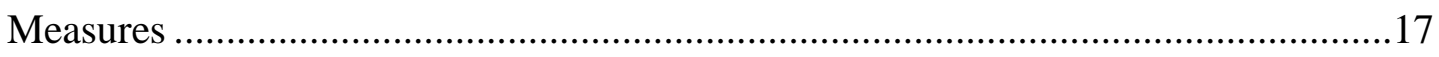

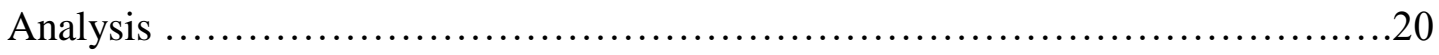

Ethical Considerations................................................20

RESULTS................................................................21

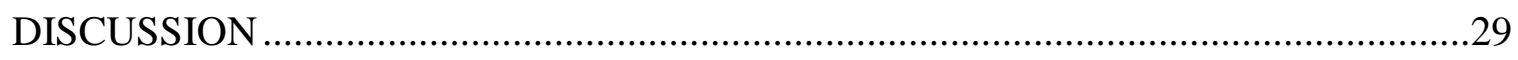

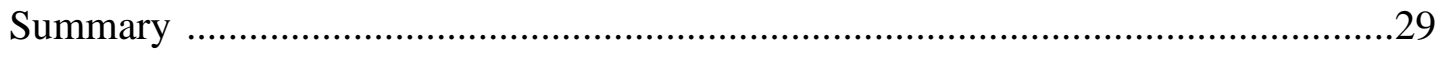

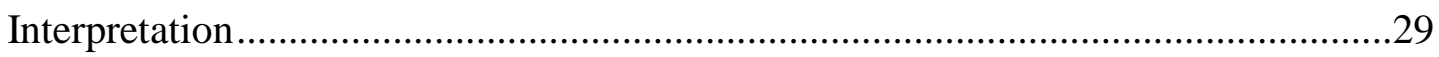

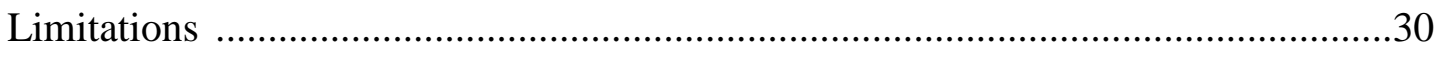

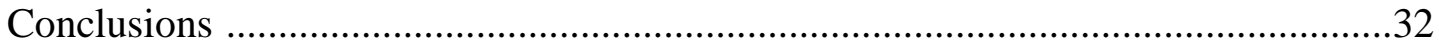

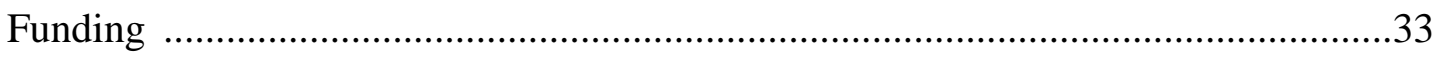

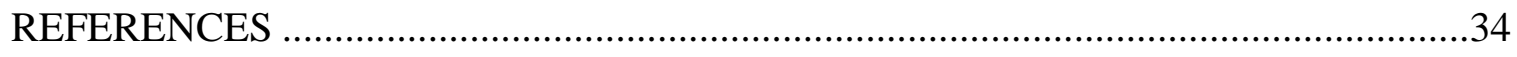

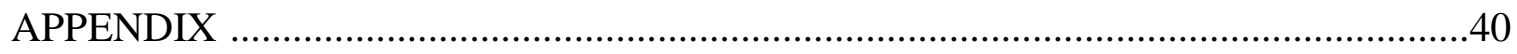




\begin{abstract}
Breast cancer screening (BCS) has been recommended to women by healthcare providers as well as professional organizations and non-profit awareness organizations for over four decades. Recently, attention is being paid to quantification of the actual benefits and harms of BCS with mammography. The harms include overdiagnosis, overtreatment and mandate of mammography screening that may not be in alignment with the individual values and preferences of women ages 40-69. This evidence translation project developed a resource for practice that was evaluated by community participants for alignment with personal value and preference-based educational needs about BCS. This project piloted a clinical practice decision aid (DA), called My Personal Decision (MPD), directly to a community-based convenience sample of women ages 40-69. Through a small sample of women, a change in knowledge about the harms and benefits of BCS was demonstrated. Evaluation feedback from the participants before and after use of the tool confirmed that MPD was helpful and enhanced preparedness for BCS decision-making. Provision of evidence-based information directly to women in the community setting was well received and perceived as valuable in the screening decision-making process in this context. Understanding of evidence-based information is a fundamental element in the empowerment of the decision maker with the goal of informed decision-making.
\end{abstract}


BREAST CANCER SCREENING DECISION AID

The evaluation of a breast cancer screening decision aid in the community setting.

\section{Introduction}

\section{Problem Description}

At this time, the cumulative evidence for breast cancer screening (BCS) does not demonstrate unquestionable benefits in the improvement of mortality with any particular method. There are well-established harms and benefits related to BCS with mammography. Conflict among professional screening recommendations provides an opportunity to encourage the empowerment of individual women in the BCS decision-making process. The use of decision aids (DA) has been clearly demonstrated to be most valuable when individual value and preference-based decisions include consideration of evidence-based harms and benefits (Stacey et al., 2017). The principle of shared decision-making (SDM) supports engagement and individual education using DAs. The HealthyUNH program has aligned their support of the SDM process within the context of community education. This provides a unique opportunity to develop and evaluate a DA resource that can be shared with women in the community setting to improve individual informed decision-making (IDM) about BCS.

\section{Available knowledge}

Background: The History of Breast Cancer Screening. Technical advances in screening for breast cancer have increased the early diagnosis and treatment of this potentially deadly disease in the United States (US) in the last 50 years. Since the 1970's, screening for early signs of breast cancer have included self-breast exam (SBE) along with clinical breast exam (CBE) with or without mammography (Picard, 1998). For SBE, evidence now questions the impact of SBE on mortality (Kosters \& Gøtzsche, 2003; Thomas et al., 2002). Follow up on the lack of evidence to support SBE, brought forth questions on the usefulness of the CBE with and without mammography.

At this time, the cumulative evidence for BCS with any method does not demonstrate unquestionable benefits in the improvement of mortality. However, distinct and concerning harms have been identified. Therefore, understanding of the nature and magnitude of harms as well as benefits is imperative for the informed decision-maker. 
BREAST CANCER SCREENING DECISION AID

The Study of Mammography and Emergence of Harms and Benefits of Screening.

The first supportive evidence for mammography in BCS was reported by the Health Insurance Plan of New York which was conducted from 1963-1986. The study examined the impact of CBE with mammography vs control group and reported a $40 \%$ relative risk reduction in mortality from breast cancer among the intervention group of women over the age of 50 compared to control. This reduction in mortality was noted to become evident 3-4 years after screening with CBE and mammography. However, the authors report: "among women aged 4049 , the benefits in terms of mortality are less clear." No benefit was directly evident with screening among this 40-49 age group in the HIP trial nor in corroborating studies at that time (Shapiro et al., 1988). Further, Shapiro et al. (1988) caution about the potentially harmful impact of the false-sense of security women receive from mammography results screening (true negative or false-negative) as well as the negative psychological and or physical sequelae from falsepositive results. The psychological and physical burden of follow-up as well as the monetary and physical cost incurred to clarify and or diagnose (biopsy) false-positive results are also identified as concerns that must be considered. Finally, Shapiro et al. (1988) encourage consideration of alternatives to mammography with reservation of its use for diagnosis vs. screening (Shapiro et al., 1988).

A 25-year cumulative study of BCS in Canada that enrolled participants between 1980 and 1985, found that there was no reduction in mortality from the use of CBE with mammography among women ages 40-59 (Miller et al., 2014). All women received annual CBE. Participants were randomized to receive annual mammography from age 40-59 or to the control group which provided CBE and usual community care between the ages 40-49 with annual mammography from age 50-59. Miller et al. (2014) reported that a total of 3250 women who received mammograms, and 3133 from the control group received a diagnosis of breast cancer. Subsequently, 500 women (between the ages of 40-59) in the mammography group, and 505 women in the control group, died of breast cancer (hazard ratio 0.99, [0.88, 1.12]) with CI of 95\%. This demonstrates that there was no difference in mortality between groups of women who had CBE with mammography between the ages of 40-49 and women who only had routine annual mammography between the ages of 50-59. Miller et al. (2014) also reported that long term (15 year) analysis revealed that 106 cases of overdiagnosis of breast cancer were observed in the mammography arm. 
In 1999, Dr. Peter Gøtzsche, Director of The Nordic Cochrane Centre and professor of Clinical Research Design and Analysis at the University of Copenhagen, reported on the harms of mammography screening in a solicited report to the Swedish parliament. At that time, Gøtzsche and his team concluded that the harms and benefits of mammography were undetermined. Thus, Gøtzsche successfully deterred the Swedish government from providing mammograms in all provinces of that nation. This provided the opportunity for comparisons between the twenty provinces where mammography was provided, and the five where it was not offered (Gøtzsche, 2015). In systematic review and meta-analysis, Gøtzsche \& Jorgensen (2013) demonstrated that deaths ascribed to any cancer were not affected by BCS. In adequately randomized controlled trials, 66013 women of all ages had screening and 66105 women of all ages did not have screening. The relative risk ratio of death from any cancer was 1.02 [0.95, 1.10] with CI of $95 \%$. Further, it was aggregated that of 119897 women of all ages who had screening, and 173061 women of all ages who did not have screening, relative risk of death from breast cancer (M-H fixed, $955 \mathrm{CI})$ after seven years was 0.93 [0.79,1.09]. Unfortunately, this minor theoretical benefit from screening was aggregated to be ten times smaller than the relative risk of potential harm from overdiagnosis and overtreatment in systematic review (Gøtzsche \& Jorgensen, 2013). In analysis, the authors' observed that for 1000 women of screening age who choose to have mammography screening, within 10 years: 100 will receive false-positive results; 22 will likely die from any cancer; 4 will likely die from breast cancer; and 5 will be overdiagnosed and overtreated. For 1000 women of screening age who choose not to have mammography screening, within 10 years: 0 will receive false-positive results; 22 will likely die from any cancer; 5 will likely die from breast cancer; and 0 will be overdiagnosed and overtreated. Yet, these are observations that are not well known to the public.

The "Malmo" randomized controlled trials (RCTs) in Sweden, on which Gøtzsche bases many of his recommendations against "routine" BCS (Gøtzsche, 2015), started in 1976. Women across a 25-year cohort (born 1908-1932) were randomized for participation in mammography screening or no participation in screening. Report of results in 1988 by Andersson et al., showed that at a mean follow-up interval of 8.8 years, 588 cases of breast cancer were diagnosed in women of all ages in the mammography group and 447 were diagnosed in the control group. Among these women, 99 women in the mammography group vs 94 women in the control group 
BREAST CANCER SCREENING DECISION AID

died of breast cancer. This is not a statistically significant difference [relative risk 0.96 [0.68, 1.35] with CI 95\%. However, for women over the age of 55, fewer women who had mammography (20\% reduction) died of breast cancer than women in the control group (35 vs 44; relative risk 0.79 [0.51, 1.24]) (Andersson, et al., 1988). Data is still collected in Sweden from this cohort in order to provide long term morbidity and mortality observation (Gøtzsche, 2015). The current Malmo trial to compare traditional mammography with breast tomosynthesis screening (ClinTrials.gov Identifier NCT01091545), started in 2010 with a new cohort of women in Sweden.

In 2014, Pace \& Keating pooled results from existing randomized clinical trials in systematic review of the impact of mammography on mortality reduction. The authors observed that across all age groups, mammography screening reduced the relative risk of overall mortality from breast cancer approximately 19\%. This represented a relative risk reduction of $15 \%$ for women in their 40's (448 events/152,300 women in the invited group vs 625 events/195,919 women in the control group) and 32\% (110 events /19,093 women in the invited group vs 155 events $/ 18,377$ women in the control group) reduction for women in their 60 's. Pace \& Keating (2014) found that among 10,000 50-year-old women who have mammograms every year for 10 years, approximately $61 \%$ will experience a false-positive result. This means that 6,130 women (95\%CI, 5800-6470) will experience a false-positive (Pace \& Keating, 2014).

Further, woman with risk factors for breast cancer were noted to demonstrate a benefit from mammography that was exponentially equivalent to their individual risk. For example, a healthy 40-year-old with two-fold increase risk for breast cancer due to increased density in her breast tissue has a correspondingly two-fold increase in benefit from annual mammography screening. Unfortunately, this also means she has a two-fold increase in risk of false-positive results (Pace \& Keating, 2014).

A cohort study in Denmark, Jorgensen et al. (2017) found that "it is likely that 1 in every 3 invasive tumors and cases of DCIS diagnosed in women offered screening represent overdiagnosis". Support of these findings is Loberg's review that found that 200 women in 1000 received a false positive result from mammography and 30 women in 1000 received a false positive result after biopsy. In this review, 2 women in 1000 were correctly identified with breast cancer and subsequently appropriately treated (Loberg et al., 2015).

Recognizing that BCS demonstrated a small amount of absolute risk and relative risk 
BREAST CANCER SCREENING DECISION AID

reduction in mortality related to breast cancer, much attention has been turned to quantification of the harms and benefits related to false positive and or false negative results. The implications of overdiagnosis and overtreatment has been evaluated by many authors in the last decade (Marmot et al., 2013; Welch et al., 2009; Welch et al., 2016).

Based on the summary of the evidence, Dr. Gøtzsche asserts that the decline in mortality from breast cancer is primarily due to improved awareness and treatment unrelated to screening behaviors (Gøtzsche, 2013; Gøtzsche, 2015). Gøtzsche further asserts: "my conclusion is that screening should be stopped because it is harmful. Also, because a quarter of women screened will get a false-positive result. In the US it is double because you are more aggressive here in the US. Screening causes overdiagnosis and kills healthy women. We must stop this.”

These harms and benefits of BCS, have encouraged health care providers as well as some community members to seek guidance about screening behaviors. Concurrently, professional health care organizations have become more and more active in the production of recommendation guidelines for the onset and frequency of screening behaviors. Professional organizational guidelines are utilized to direct the behavior of healthcare providers and women throughout the United States (US). As such, it is important to understand which guidelines are based on high quality evidence and how women can best become aware of recommendations and consider incorporation of them in IDM about screening behaviors.

Professional Organization Recommendation Guidelines. With growing scientific information about the harms of BCS, task forces, review groups and expert panel discussions were established to review the evidence and recommend best practice guidelines for BCS activities. Consequently, several professional health care organizations have come forward with BCS recommendation guidelines to influence the manner and frequency of screening for women of varying age groups. These organizations include the American Cancer Society (ACS), the United States Preventative Services Task Force (USPSTF) and the American Congress of Obstetricians and Gynecologists (ACOG). Many other professional organizations have released guidelines as well including, the National and Comprehensive Cancer Network (NCCN), the American College of Radiology (ACR) and the Society of Breast Imaging (SBI). A summary of current recommendation guidelines can be viewed in Table 1. The historical development of guidelines by three of these professional health care organizations, ACS, USPSTF and ACOG is presented in the following text. 


\begin{tabular}{|c|c|c|c|c|c|}
\hline & ACS & USPSTF & ACOG & ACR/SBI & $\mathrm{NCCN}$ \\
\hline $\begin{array}{l}\text { CBE } \\
\text { Recommen- } \\
\text { dation }\end{array}$ & $\begin{array}{l}\text { Not } \\
\text { Recommended }\end{array}$ & $\begin{array}{l}\text { Not } \\
\text { Recommended }\end{array}$ & $\begin{array}{l}\text { Age } \geq 19 \text { years: } \\
\text { Annual } \\
\text { All: Instruction } \\
\text { of "Breast Self- } \\
\text { Awareness" }\end{array}$ & None & $\begin{array}{l}\text { Age } 25-40 \\
\text { years: } \\
\text { every 1-3 years } \\
\text { Age > 40: } \\
\text { annual } \\
\text { All: Instruction } \\
\text { of "Breast } \\
\text { Awareness" }\end{array}$ \\
\hline $\begin{array}{l}\text { Mammog- } \\
\text { raphy } \\
\text { Screening } \\
\text { Initiation }\end{array}$ & $\begin{array}{l}\text { Age } 40-44, \\
\text { option to have } \\
\text { annual } \\
\text { screening } \\
\text { Age } 45-54 \\
\text { years: Annual }\end{array}$ & $\begin{array}{l}\text { Age 40-49 } \\
\text { years: } \\
\text { Decision to } \\
\text { begin screening } \\
\text { should be } \\
\text { individual }\end{array}$ & $\begin{array}{l}\text { Age } \geq 40 \text { years: } \\
\text { Annual - } \\
\text { biennial } \\
\text { consideration } \\
\text { of harms and } \\
\text { benefits } \\
\text { through shared } \\
\text { decision- } \\
\text { making. }\end{array}$ & $\begin{array}{l}\text { Age }>40 \\
\text { years: Annual }\end{array}$ & $\begin{array}{l}\text { Age } \geq 40 \text { years: } \\
\text { Annual } \\
\text { Consider } \\
\text { tomosynthesis }\end{array}$ \\
\hline $\begin{array}{l}\text { Subsequent } \\
\text { Mammog- } \\
\text { raphy } \\
\text { Screening }\end{array}$ & $\begin{array}{l}\text { Age } \geq 55 \text { years: } \\
\text { Biennial } \\
\text { (as long as } \\
\text { overall health } \\
\text { is good with } \\
\text { life expectancy } \\
>10 \text { years) }\end{array}$ & $\begin{array}{l}\text { Age } 50-74 \\
\text { years: Biennial } \\
\text { Age } \geq 74 \text { years: } \\
\text { Insufficient } \\
\text { evidence to } \\
\text { assess benefits } \\
\text { and harms of } \\
\text { screening) }\end{array}$ & $\begin{array}{l}\text { Age 50-75 } \\
\text { years: As } \\
\text { above } \\
\text { (particularly } \\
\text { after age 55) }\end{array}$ & As above & As above \\
\hline Source & ACS, 2016 & Siu, 2016 & ACOG, 2017 & ACR, 2016 & NCCN, 2017 \\
\hline
\end{tabular}

The American Cancer Society (ACS). Initial BCS guidelines from the ACS emerged after the HIP trial started in New York in 1963. The purpose of the HIP trial was to study the effects of as a mammography as a screening tool for breast cancer, on the mortality of women (Lerner, 2003). Mammography was developed in the early 1900's as a diagnostic tool for breast cancer. Although not well received until the 1960's the use of mammography for diagnosis was embraced in the mid-1960's (Houssami \& Miglioretti, 2016).

At that time, the ACS published recommendations that directed women to begin SBE in the teen years and consider mammography at the age of 35 if they have a personal history of breast cancer. At that time, the ACS further recommended that women between the ages of 40 and 49, with a first-degree relative with breast cancer, should undergo mammography while all 
BREAST CANCER SCREENING DECISION AID

women should consider annual mammograms starting at the age of 50 (ACS History, 2017).

In 1983, the ACS changed their original recommendation and released guidelines that encouraged women 20 and over to perform SBE monthly, have CBE every three years and begin annual CBE at the age of 40. Mammography was recommended for baseline at age 35 with annual - biennial mammography between ages 40 and 49. Annual mammograms were recommended beginning at age 50. In 1997 annual mammography recommendation was moved to age 40 and remains at that interval until 2015 (ACS History, 2017).

The 2015 guideline update from the ACS (Oeffinger et al., 2015) increased the recommended age of initiation of annual mammography screening, for women who are of average risk for the development of breast cancer in their lifetime, from 40 (Oeffinger et al., 2015 ) to 45 to 54 with biennial mammography recommended to begin at the age of 55 . This was upheld by the ACS in 2016 (ACS, 2016).

The United States Preventative Services Task Force (USPSTF). In 1984 the USPSTF established an expert panel that was chartered by legislation to review scientific evidence and provide recommendations to clinical experts, clinicians and the public about preventative healthcare (USPSTF, 2002). The USPSTF is prohibited by law from consideration of cost effectiveness in screening program recommendations (AHRQ, 2017). By end of the $20^{\text {th }}$ century, the Mammography Quality Standards Act (MQSA) was established in the US and lower doses of radiation per exam and standardization of reporting were mandated (US Food \& Drug Admin, 2017). In 1997, an NIH Consensus Conference concluded "the data currently available do not warrant a universal recommendation for mammography for all women in their forties. Each woman should decide for herself whether to undergo mammography" (NIH, 1997). Despite this, the US Senate subsequently voted 98-0 in favor of provision of BCS for women in their 40's. Subsequently, a windfall of data was published in the medical literature and the USPSTF reviewed and updated their recommendation in 2002 to state that women in their 40's should have mammography screening every 2 years (USPSTF, 2002).

In 2009, the USPSTF updated their guidelines to remove routine recommendations for average risk women before the age of 50 stating "The decision to start regular, biennial screening mammography before the age of 50 years should be an individual one and take patient context into account, including the patient's values regarding specific benefits and harms." In an unprecedented recommendation, biennial mammography for women 50-74 years was 
BREAST CANCER SCREENING DECISION AID

recommended. Insufficiency of evidence to assess the benefits and harms of screening mammography in women 75 years and older was also reported in the 2009 USPSTF guideline (USPSTF, 2009).

In 2016, after systematic review and meta-analysis of the harms and benefits of BCS, the USPSTF released guidelines that enunciated the recommendations under which women under the age of 40 should undergo CBE with or without mammography. It was in this detailed guideline that concern about overdiagnosis, overtreatment and false-positive results was delineated for average risk women between 40 and 49 years of age. However, the need for individual preference-based decision-making about beginning mammography before age 50 was also advised (Siu, 2016).

The ACS published criticism of the USPSTF stating women should be guided to begin annual mammography at the age of 40 (ACR \& SBI, 2016). Debra Monticciolo, MD of the ACR stated "following these USPSTF recommendations would result in lethal consequences for thousands of women each year." The ACR and SBI further contended that reports of overdiagnosis are "vastly inflated" as they include ductal carcinoma in situ (DCIS). And they state "few, if any, invasive cancers are over-diagnosed" (ACR \& SBI, 2016).

The American Congress of Obstetricians and Gynecologists (ACOG). Based on public, clinical and academic debate, along with the recognized lack of corroborating recommendations, ACOG convened a "multidisciplinary forum" in January 2016 "to address the need for harmony among recommendations." An extensive statement, that outlined the key points for IDM was published in May 2016. In June of 2017, ACOG released an update to prior recommendations that emphasized early recognition of and intervention for breast cancer. Breast cancer is recognized by ACOG as the second leading cause of cancer death among US women. While regular screening mammography starting at age 40 is credited with reducing breast cancer mortality in average-risk women, the potential harms of screening such as "false-positive test results and overdiagnosis of biologically indolent lesions" (ACOG, 2017). However, while continuing to underline the value of screening mammography and its role in reduction of mortality related to breast cancer, the recommendation for shared decision-making across the lifespan was underscored in this updated guideline. According to ACOG, women's health-care providers should provide the opportunity for women between the ages of 40-75, who are at average risk for breast cancer, to engage in shared decision-making that includes discussion 
BREAST CANCER SCREENING DECISION AID

about benefits and harms of mammography every 1-2 years. Further, ACOG (2017) guidelines recommend that women are encouraged to have a mammogram by the age of 50 with subsequent shared decision-making opportunities, to address the frequency of ongoing screening every 1-2 years until the age of 75 .

In the context of these complicated and conflicting recommendations about the benefits as well as harms of BCS, there are many challenges to IDM for women who are between the ages of 40 and 75 and are determined to be at average-risk for breast cancer.

\section{Rationale}

Informed Decision-making. The process of IDM involves the use of evidence to guide decisions on the part of an individual. The decision to undergo BCS provides medically reasonable alternatives based on the value of the harms and benefits implicit in the applied technology, in this case, mammography. IDM in this context supports the acquisition of preemptive knowledge of these harms and benefits.

The principle of SDM replies upon the incorporation of IDM in a process that is shared between the patient and the provider. SDM is the process of sharing information between a healthcare provider and patient, when there are options or choices that have unique benefits and harms. The provider shares evidence-based information about the benefits and harms of the choices available, and the patient weighs this in light of their own values and preferences, to ultimately make the decision at hand. SDM has been demonstrated to improve healthcare and reduce costs (O'Connor et al., 2004).

Reports about the harms and benefits of BCS in the medical literature, media and in printed pamphlets are subject to (among other things), the influence of selective reporting, commercial influence, defensive practice, statistical illiteracy and over-estimation of treatment benefits. Further, time constraints on provider-patient consultations can limit interactions and prevent effective information sharing. HCPs are noted to report relative risk reduction more frequently than the more objective report of absolute risk reduction as advocated by established best practice. Importantly, provision of information to patients outside of the clinical encounter is noted to improve the balance of the provider-patient relationship and enhance preparedness for the counseling discussion (Bodemer \& Gaissmaier, 2012).

Based on these variables, the decision to undergo mammography screening among 
BREAST CANCER SCREENING DECISION AID

women aged 40-49 is recommended by ACOG and the USPSTF to take place in the context of

IDM. The resultant shared decision between the provider and female patient should be based on the individual values and preferences of the individual as informed by the existing medical evidence. Based on the prior evidence related to screening by Gøtzsche \& Jorgensen (2013) as well as the high level of evidence by the USPSTF recommendations (Siu, 2016) and ACOG's (2017) emphasis on shared decision-making across the life span, it is clear there is a need for informed decision-making about BCS by women between the ages of 40-75. For the purposes of this project, women between the ages of 40-69 were targeted to receive the DA and provide feedback. This population of women are able to utilize the information for a minimum of 5 years into the future and thus provide value-based responses about helpfulness and preparedness in decision-making.

\section{Breast Cancer Screening as a Preference-Sensitive Care Decision and Decision Aids.}

When there is more than one acceptable option for screening, diagnosis and or treatment in healthcare, the decision-making process is considered to be preference-sensitive, i.e. based on the preference of the patient. Decisions that involve "tradeoff's affecting the patient's quality and/or length of life" (Dartmouth Atlas, 2007) should reflect the values and preferences of the patient and family. In a systematic assessment of benefits and harms to guide BCS decisions, Pace \& Keating. (2014) asserted that individualized screening decisions based on the perception of individual risk and value-based preferences are important for effective and satisfactory healthcare.

It is asserted that the US healthcare system suffers from "unwarranted variation" due to the underuse of effective care, the misuse of preference-sensitive care and the overuse of supplysensitive care (Dartmouth Atlas, 2007). In healthcare, the misuse of preference-sensitive care occurs when the harms and benefits of a screening and or treatment decision are not effectively communicated and therefore, the choice made is not based on the values of preferences of the patient (Dartmouth Atlas, 2007). To avoid this unwarranted variation, the use of SDM and DAs in BCS has been validated by evidence-based medicine for more than a decade (Gunn, 2015; O’Connor et al., 2004). DA's are defined by Cochrane (Stacey et al., 2017) as "interventions designed to support patients' decision-making by making explicit the decision, providing information about treatment or screening options and their associated outcome."

Prior publications have focused on the impact of timing of the decision as related to 
mammography screening participation. The use of DAs in preference-sensitive BCS decisionmaking by adult women has been examined by randomized control trials (Bourmaud et al., 2016; Schapira et al., 2016; Hersch et al., 2015; Mathieu et al., 2010). These trials all provided a DA to women outside of an encounter with a health care provider in the community setting. Written material and/or a web link for an online DA was sent by mail directly to the home of the women registered with the government for nationalized healthcare services outside of the US as was accomplished in this MPD project. Prior trials demonstrate that women who utilized a DA in the community setting are more likely to either seek and obtain mammography screening sooner than their control counterparts, or defer screening mammography, based on individual values and preferences (Bourmaud et al., 2016; Hersch et al., 2015; Mathieu et al., 2010). This preference and value-based expression of decision-making aligns with the mandate from within the US healthcare system imposed by ACOG (2016).

Cost-Benefit analysis (Table 2) revealed project benefits and as such the project commence with support from Dr. Gene Harkless, Chair, Department of Nursing, University of New Hampshire.

\begin{tabular}{|c|c|}
\hline $\begin{array}{c}\text { Strengths } \\
\text { *Transparent process with clear goals } \\
\text { *Informative communication to community } \\
\text { *Paperless (web-based) interactive process } \\
\text { *Empowerment of individualized decision-making } \\
\text { based on values and preferences } \\
\text { *Reduction in unnecessary screening } \\
\text { *More effective appropriation of healthcare funds } \\
\text { related to mammography overuse } \\
\text { *Enhancement of HealthyUNH support of SDM }\end{array}$ & $\begin{array}{l}* \text { Time consuming process for unique evidence-based } \\
\text { DA tool development }\end{array}$ \\
\hline $\begin{array}{c}\text { Opportunities } \\
\text { *Enhancement of individualized BCS decision-making } \\
\text { based on values and preferences } \\
\text { *Service to UNH community } \\
\text { *Improvement in maturity of UNH organizational } \\
\text { maturity r/t healthcare education } \\
* \text { Cultural Change }\end{array}$ & $\begin{array}{l}\text { Threats } \\
\text { *Resistance to apply unique DA to other topics due to } \\
\text { time consuming DA development process (desire to } \\
\text { implement pre-existing educational material provided } \\
\text { by insurer) } \\
\text { *Stakeholders (UNH community, UNH HR, corporate } \\
\text { insurer) potential resistance to change } \\
* \text { Cultural Change }\end{array}$ \\
\hline
\end{tabular}

\section{Specific aims}

The purpose of this quality improvement project was to pilot a clinical practice DA to provided evidence-based information about the harms and benefits of BCS directly to a 
BREAST CANCER SCREENING DECISION AID

convenience sample of women at average risk for breast cancer between the ages of 40 and 69 in the community setting. The specific aim of this project is to enhance preparedness for decisionmaking through provision of a DA that is perceived as helpful to the user. This evidence translation project first developed a DA resource for practice called "My Personal Decision" (MPD) based on systematic review as presented in an educational leaflet. This leaflet titled: "Screening for breast cancer with mammography" (Gøtzsche et al., 2012), was published by the Nordic Cochrane Center and used with permission from primary author Dr. Peter Gøtzsche. The presentation was evaluated by community participants for alignment with personal value and preference-based educational needs, usefulness and influence on personal beliefs about BCS. This presentation was not for women who have a personal history of breast cancer or family history of breast cancer in a first-degree relative (such as a mother or sister) or other factors that make them at high risk for breast cancer.

\section{Methods}

\section{Context}

A convenience sample of women in the general community setting was solicited through social media and email invitation by other community women. Minimal restrictions were imposed on participants beyond request for women between the ages of 40 and 69, who are not known to be at high risk (thus by default average risk) for breast cancer. A general community sample was deemed advantageous for its relatively heterogeneous composition across educational preparations, socioeconomic backgrounds, cultural expectations and religious preferences.

\section{Intervention}

There were two components of the intervention. First, the presentation was compiled from systematic review and based on the publication leaflet "Screening for breast cancer with mammography” as published by the Nordic Cochrane Center (Gøtzsche et al., 2012). This DA was chosen as foundation for this project based on its formation from systematic review as well as its ability to inform individualized value and preference-based BCS decision-making in accordance with International Patient Decision Aid Standards (Elwyn et al., 2006). 
BREAST CANCER SCREENING DECISION AID

The educational leaflet "Screening for breast cancer with mammography" was initially developed in 2008 by Dr Peter Gøtzsche for distribution to women through the National Board of Health in Denmark (Gøtzsche et al., 2012). Development of the leaflet was driven by concerns about misrepresentation of the benefits of BCS in similar educational leaflets in the United Kingdom. Primary author Gøtzsche states that materials in prior leaflets were "insufficient, onesided and erroneous" in their actual risk representations. In 2012 the leaflet was updated and republished with the opening statement acknowledging recent improvement in early treatment of breast cancer. This advance in treatment has led to the observation in randomized controlled trials that mammography screening is no longer beneficial in significant reduction of risk of dying from breast cancer (Gøtzsche et al., 2012). This leaflet has subsequently been favorably evaluated by multiple authors (Gummersbach et al., 2015; Henriksen et al., 2015; vanAgt et al., 2014). The content of the leaflet was extracted as guided by Elkin et al., (2017), Saver et al. (2017), Yi et al. (2015), Stacey et al. (2014), and outlined in Microsoft@ PowerPoint presentation with corresponding narrative script. Actual risk content was portrayed in "theater images" as described in Rifkin \& Lazris (2015). The title MPD was adopted and the presentation was recorded for video presentation.

The second component of the intervention was provision of MPD to the community. As previously stated, the DA, MPD was trialed in the community setting with a convenience sample of women ages 40-69. The convenience sample was solicited through social media contact facilitated by the author and through notification via newsletter by the HealthyUNH program. No attempt to control participant attributes was made beyond pre-test questions that identify participant age and risk status for breast cancer. A link to the online presentation MPD in narrated video format included the pre- and post-evaluation usefulness, integrity of value and preference-based decision-making it produces as well as impact on decision intent and decisional conflict experienced by users. The presentation was available for a period of 2 weeks with a convenience sample of 66 participants at the time of review of the evaluation data.

Collaboration with faculty mentor Dr. Gene Harkless was undertaken at each step in the intervention plan process for MPD. Permission for use of the leaflet "Screening for breast cancer with mammography" and its contents was provided by Dr. Peter Gøtzsche by email, and the source was cited within the presentation and in all supporting documents. The project was 
BREAST CANCER SCREENING DECISION AID

support by the HealthyUNH program for personal and professional development purposes. However, no financial support was provided by HealthyUNH or any other outside source.

\section{Study of the Intervention}

Qualtrics survey software was utilized to present and collect quantitative data immediately prior to and after presentation of MPD. This concise (14 question total) pre- and post-evaluation tool was developed based on the expectancy value theory as described by Eccles (1983) in which expectancies for success, and subjective task values are noted to determine the experienced value of an educational activity. The pre-post evaluation instrument is provided in Appendix A. Data was collected at the point of entry to the MPD link by question and response in the Qualtrics software.

\section{Measures}

Pre- and post-evaluation/test data was exported and analyzed in JMP software (SAS, 2017) to validate individual reliability of understanding of the questions by mosaic plot, and to determine knowledge shift by development of 5 by 5 contingency table with subsequent evaluation of Fisher's Exact Test and Bowker's test. Generation of understanding of the value and utility of the presentation as well as the impact of MPD on the screening decision was evaluated through observation of numeric results and review and categorization of presentation comments.

Weekly review of data for observation of comments and suggestions as well as overt patterns of response was completed by this student and faculty advisor. This continued until 4-818 when formal data analysis commenced as described above. Subtle changes were made based on feedback from participants and are noted in the timeline within Table 3. Monetary and emotional costs were not noted through that process. After data collection, the decision was made to continue to keep the presentation open to continue to accumulate information about this DA. 


\section{Table 3. Evolution of project: Timeline}

\begin{tabular}{|c|c|c|}
\hline Goals & Objectives & Expected Outcomes \\
\hline $\begin{array}{l}\text { 1. This student will identify } \\
\text { valid evidence-based DA about } \\
\text { BCS and created unique } \\
\text { presentation called MPD to } \\
\text { convenience sample of women } \\
\text { ages } 40-69 \text { in community } \\
\text { setting. }\end{array}$ & $\begin{array}{l}\text { 1. To adopt valid, objective, evidence- } \\
\text { based DA for presentation and use in } \\
\text { BCS decision-making by women ages } \\
40-69 \text { for improvement of } \\
\text { individualized value and preference- } \\
\text { based decision-making. }\end{array}$ & $\begin{array}{l}\text { 1. Adoption of DA and creation of } \\
\text { presentation as described. }\end{array}$ \\
\hline \multicolumn{3}{|c|}{$\begin{array}{l}\text { Initial Goal date: } 10 / 1 / 17 \\
\text { Delay attributed to unexpected modifications, need to receive training and IT support for enhanced functionality } \\
\text { of Qualtrics platform. Additional goal added to obtain permission and support from Nordic Cochrane Center. } \\
\text { Actual date: } 12 / 14 / 17\end{array}$} \\
\hline $\begin{array}{l}\text { 2. This student will disseminate } \\
\text { MPD by email invitation with } \\
\text { link to web-based tool that will } \\
\text { evaluate pre- and post-intent for } \\
\text { screening and decisional conflict } \\
\text { with post value/utility as a DA. }\end{array}$ & $\begin{array}{l}\text { 2. To swiftly and effectively } \\
\text { disseminate MPD to small convenience } \\
\text { sample that is easy to use and increases } \\
\text { likelihood of individual participation. }\end{array}$ & $\begin{array}{l}\text { 2. Effective and efficient } \\
\text { solicitation of participation that } \\
\text { encourages/supports small } \\
\text { convenience sample of } 75-100 \\
\text { participants. }\end{array}$ \\
\hline \multicolumn{3}{|c|}{$\begin{array}{l}\text { Initial goal date: } 10 / 30 / 17 \\
\text { Delay attributed to delay in presentation finalization as well as holiday ( } 5 \text { week) break that separated faculty and } \\
\text { student from ability for ongoing consultation. HealthyUNH dissemination was paused mid-February due to } \\
\text { concerns about potential perception of provision of financial support by community members. The eventual } \\
\text { decision to pursue distribution individually through social media contact was made and performed on } 2 / 27 / 18 \text {. } \\
\text { After initial posting and } 6 \text { participants, it was noted that it was possible to separate instructions and presentation } \\
\text { link. Thus, instructions were moved from social media posting to inclusion as item \#1 in Qualtrics survey. } \\
\text { Reference list was initially included in the video presentation but was replicated, based on feedback, in the } \\
\text { conclusion (thank you page) of the Qualtrics survey after } 20 \text { participants were recorded. HealthyUNH } \\
\text { dissemination of presentation link was pending at the time of this report. } \\
\text { Actual date: } 2 / 27 / 18\end{array}$} \\
\hline $\begin{array}{l}\text { 3. This student will analyze data } \\
\text { for impact on preparation for } \\
\text { decision-making about BCS, } \\
\text { perceived usefulness of MPD. }\end{array}$ & $\begin{array}{l}\text { 3. To identify the usefulness of MPD as } \\
\text { related to impact on preparation for } \\
\text { decision-making about BCS and } \\
\text { perceived overall usefulness of MPD. }\end{array}$ & $\begin{array}{l}\text { 3. Descriptive and statistical data } \\
\text { that enunciate the perceived } \\
\text { usefulness of this type of DA and } \\
\text { impact on preparation for decision- } \\
\text { making that can be replicated and } \\
\text { or utilized in future practice } \\
\text { changes. }\end{array}$ \\
\hline \multicolumn{3}{|l|}{$\begin{array}{l}\text { Initial goal date: } 2 / 28 / 18 \\
\text { Delay due to prior delays. } \\
\text { Actual data: } 4 / 1 / 18\end{array}$} \\
\hline $\begin{array}{l}\text { 4. This student will report } \\
\text { finding results in visual and } \\
\text { written format. }\end{array}$ & $\begin{array}{l}\text { 4. To present findings in effective } \\
\text { manner that verifies completion of } \\
\text { requirements of DNP project and } \\
\text { outlines practice changes that can be } \\
\text { implemented in future practice settings. }\end{array}$ & $\begin{array}{l}\text { 4. Well received presentation of } \\
\text { results in visual and written format } \\
\text { that are considered for publication. }\end{array}$ \\
\hline $\begin{array}{l}\text { Initial goal date: } 4 / 30 / 18 \\
\text { Actual date: } 4 / 30 / 18\end{array}$ & & $\begin{array}{l}\text { Initial goal date: } 9 / 1 / 18 \\
\text { Revised goal date: } 6 / 30 / 18\end{array}$ \\
\hline
\end{tabular}

Completeness and accuracy of data was assessed through review of the recorded data and pattern of missing data evaluation. 66 people were noted to participate in the presentation. It was 
noted that the post-evaluation results for only 42 people were documented in Qualtrics®. Upon consultation with Dr. Phil Ramsey, he stated "that the statistical probability that this pattern of data omission occurred randomly is nil" It was postulated by Dr. Ramsey that a technical error in Qualtrics ${ }^{\circledR}$ was more likely than a lack of participant response to cause this type of omission. However, most participants a positive response to the usefulness of the tool and assistance with decision-making in the form of supportive comments and or neutral observations (Table 4) was noted. Therefore, evaluation of the response data commenced as planned based on 42 completed responses.

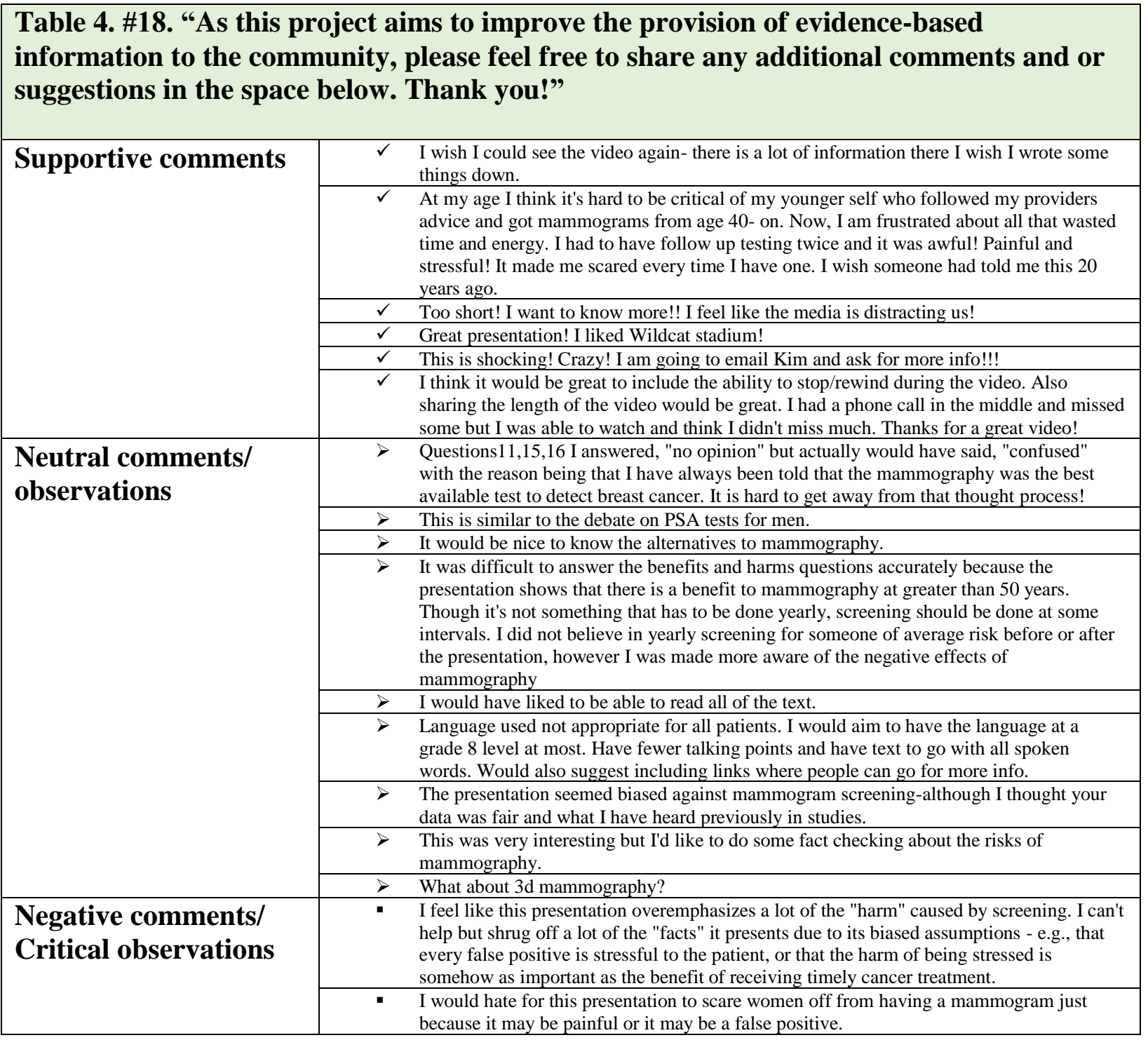


BREAST CANCER SCREENING DECISION AID

\section{Analysis}

Two similar questions were asked prior to the presentation: "\#4. There are more benefits than harms related to breast cancer screening (mammography)" and "\#5. There are more harms than benefits related to breast cancer screening (mammography)." The purpose of the questions was to establish that respondents understood the questions being asked and establish belief in regard to the concepts of harm and benefits related to BCS. The responses were examined for inverse relationship in order to reflect participant understanding of the questions and corresponding consistency in response.

Contingency Tables were generated, Fisher's Exact Test results observed for Probability > Chi-squared which provides the probability that chance alone can produce a Chi-squared value greater than the calculated value in the absence of a relationship between the variables.

Subsequently, Bowker's test was applied to the matched set of pre- and post-evaluation questions for symmetry of disagreement thus reflecting change in knowledge and opinion before and after MPD.

The final step in analysis was report of actual results of post-evaluation questions that provided feedback about usefulness and helpfulness of the presentation. Categorization of feedback comments as supportive, neutral and negative/critical provided anecdotal observations and suggestions for future improvement and are presented in Table 4 as previously reported.

\section{Ethical Considerations}

UNH Internal Review Board (IRB) approval is not necessary due to the quality improvement intent for this project. However, ethical consideration related to the collection of data includes adherence to Health Insurance Portability and Accountability Act of 1996 (HIPPA) to protect the privacy of individual patient information. For both community members and employees of $\mathrm{UNH}$, the protection of privacy of electronic communication in the completion of the pre- and post-test questionnaires as mandated by the Electronic Communications Privacy Act of 1986 (ECPA) (Federal Privacy Council, 2016) is acknowledged and guided the further protection of privacy of data collected. No identified list of participants was collected and only ISP identifiers were gathered by Qualtrics. This was separated from data prior to aggregation. All electronic files that contain ISP information (prior to de-identification and aggregation) are 
BREAST CANCER SCREENING DECISION AID

password protected and isolated from unauthorized use by people other than this student and the faculty mentor. No further identifiable information was collected.

Further ethical consideration related to the impact of the information provided was considered in the context of empowerment of individualized decision-making with acknowledgment about the harms and benefits of BCS. As such, voluntary participation was solicited and the MPD presentation included only evidence-based presentation of these harms and benefits as established by Gøtzsche \& Jorgensen (2013), Hersch et al. (2015), Jorgensen et al. (2017) Loberg et al. (2015), Pace \& Keating (2014) and Welch et al. (2016). This information is acknowledged to be contrary to popular media campaigns that advocate for mammography screening at ages prior to those noted to be beneficial through evidence-based research.

Additionally, it is acknowledged that the harms of mammography, particularly overdiagnosis and overtreatment, are under acknowledged in professional recommendations as well as in the public media, and may be surprising and concerning to some participants (Gøtzsche, 2015). In recognition of this, a complete description of the intent of the project as quality improvement and basis on well-established evidence-based research was provided prior to the content of MPD. Additionally, the choice of a tool that was based on systematic review and validated through previous study was made to reduce the risk of conflict related to a potentially invalidated tool. Contact information for the student presenter was provided at the beginning of the program as well as in the introduction provided on the initial social media post.

\section{Results}

The initial steps of the MPD intervention process and the evolution over time are reported in Table 3. Minor modifications were made to the intervention presentation in Qualtrics® during the project and are reported in Table 3. No changes to the video presentation, questions or content were made after initial dissemination. As previously stated, pre- and post-evaluation data was exported from Qualtrics® and analyzed in JMP software (SAS, 2017). JMP labeled results with warning "Warning: $20 \%$ of cells have expected count less than 5. ChiSquare is suspect. Warning: Average cell count less than 5, LR ChiSquare suspect." This warning is elicited by the small sample size. Although while results are not noted to demonstrate a true difference for this small sample size, findings are noted to be informative about the understanding and change in belief before and after presentation as follows. 
BREAST CANCER SCREENING DECISION AID

Initially, it was important to note that there is an inverse relationship between the two similar questions: “\#4. There are more benefits than harms related to breast cancer screening (mammography)" and “\#5. There are more harms than benefits related to breast cancer screening (mammography)." (Table 5), thus validating a pattern of consistency in response. The likelihood that the difference is from chance is less than $0.01 \%(\mathrm{p}<.0001)$. Based on the observation that participants understood the questions, subsequent analysis proceeded.

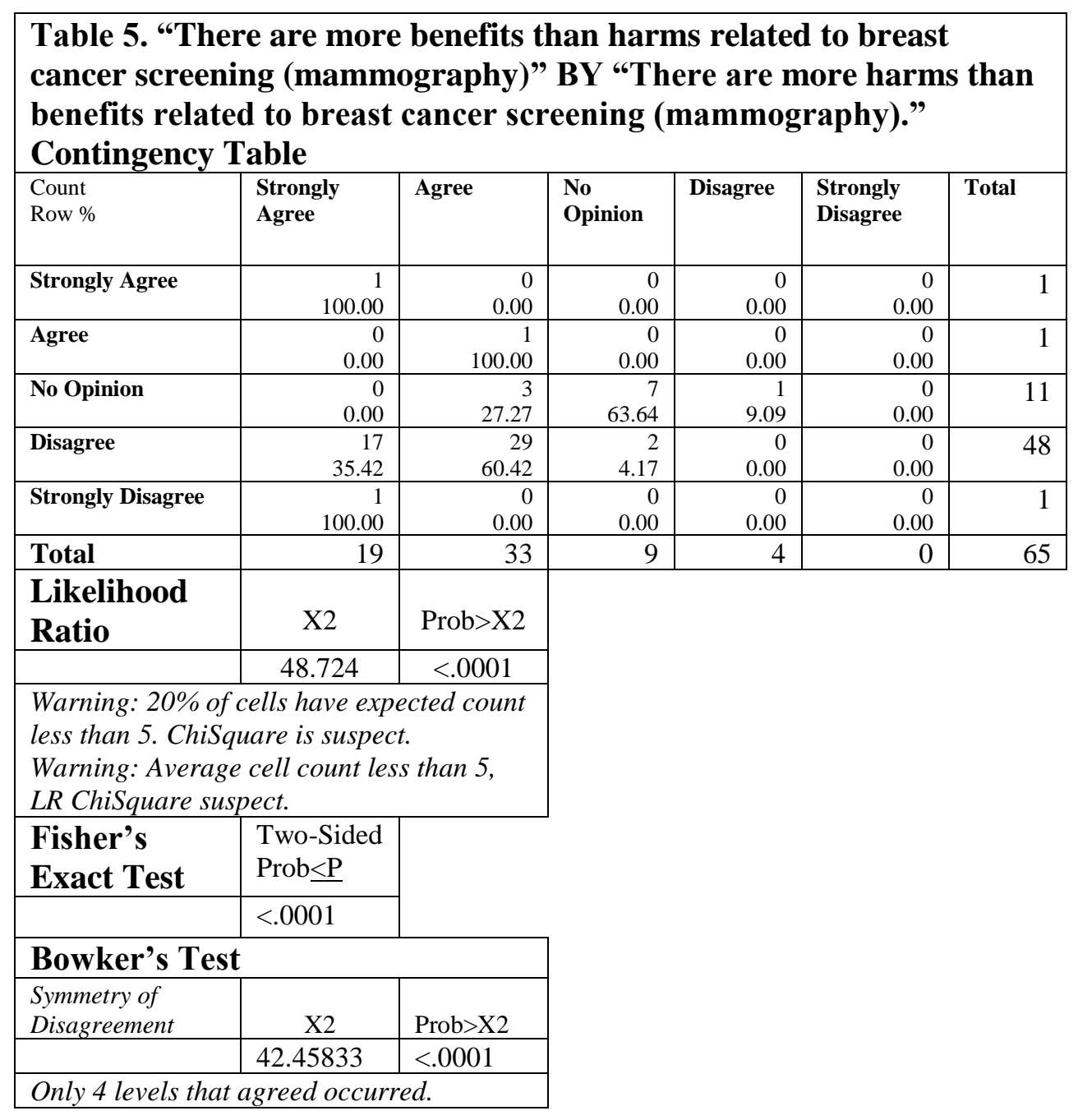

Bowker's test for symmetry of disagreement was applied to the pre- and post-questions to determine if opinion about benefits and harms changed post presentation. A change was noted, from pretest to posttest, in opinion for the question: "There are more benefits than harms related to breast cancer screening (mammography)" (Table 6). In actual terms, 36 participants 
BREAST CANCER SCREENING DECISION AID

agreed/strongly agreed to the statement before the presentation, while 19 people agreed/strongly agreed after the presentation. The Fisher's Exact Test confirmed the presence of the findings as noted in Table 6.

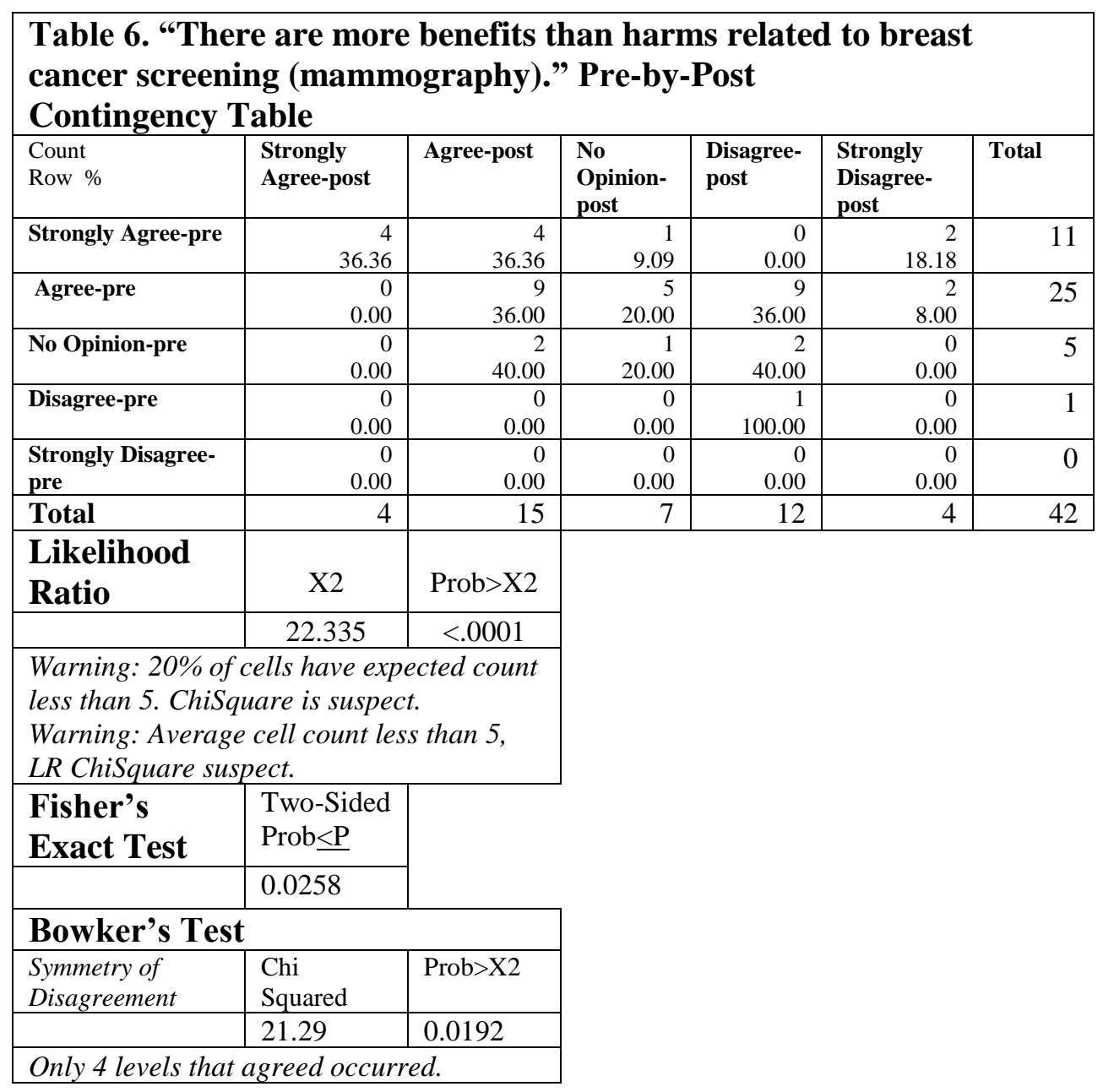

Further, 14 out of 34 participants changed response from disagreement that harms outweigh benefits toward agreement that harms outweigh the benefits of BCS (Table 7). Only 1 participant agreed/strongly agreed there are more harms than benefits prior to the presentation and 20 agree strongly agree responses were recorded in post-evaluation to the same statement. Six out of seven people who declared no opinion to the statement that harms outweigh the benefits of BCS changed their response to agree/strongly agree after the DA. 
BREAST CANCER SCREENING DECISION AID

\begin{tabular}{|c|c|c|c|c|c|c|}
\hline \multicolumn{7}{|c|}{$\begin{array}{l}\text { Table 7. "There are more harms than benefits related to breast } \\
\text { cancer screening (mammography)." Pre-by-Post } \\
\text { Contingency Table }\end{array}$} \\
\hline $\begin{array}{l}\text { Count } \\
\text { Row \% }\end{array}$ & $\begin{array}{l}\text { Strongly } \\
\text { Agree-post }\end{array}$ & $\begin{array}{l}\text { Agree- } \\
\text { post }\end{array}$ & $\begin{array}{l}\text { No } \\
\text { Opinion- } \\
\text { post }\end{array}$ & $\begin{array}{l}\text { Disagree- } \\
\text { post }\end{array}$ & $\begin{array}{l}\text { Strongly } \\
\text { Disagree- } \\
\text { post }\end{array}$ & Total \\
\hline Strongly Agree-pre & $\begin{array}{r}0 \\
0.00\end{array}$ & $\begin{array}{r}0 \\
0.00\end{array}$ & $\begin{array}{r}0 \\
0.00\end{array}$ & $\begin{array}{r}0 \\
0.00\end{array}$ & $\begin{array}{r}0 \\
0.00 \\
\end{array}$ & 0 \\
\hline Agree-pre & $\begin{array}{r}0 \\
0.00\end{array}$ & $\begin{array}{r}1 \\
100.00\end{array}$ & $\begin{array}{r}0 \\
0.00\end{array}$ & $\begin{array}{r}0 \\
0.00\end{array}$ & $\begin{array}{r}0 \\
0.00\end{array}$ & 1 \\
\hline No Opinion-pre & $\begin{array}{r}3 \\
42.86 \\
\end{array}$ & $\begin{array}{r}3 \\
42.86 \\
\end{array}$ & $\begin{array}{r}0 \\
0.00\end{array}$ & $\begin{array}{r}1 \\
14.29\end{array}$ & $\begin{array}{r}0 \\
0.00\end{array}$ & 7 \\
\hline Disagree-pre & $\begin{array}{r}3 \\
9.09\end{array}$ & $\begin{array}{r}10 \\
30.30\end{array}$ & $\begin{array}{r}2 \\
6.06\end{array}$ & $\begin{array}{r}15 \\
45.45\end{array}$ & $\begin{array}{r}3 \\
9.09\end{array}$ & 33 \\
\hline $\begin{array}{l}\text { Strongly Disagree- } \\
\text { pre }\end{array}$ & $\begin{array}{r}0 \\
0.00 \\
\end{array}$ & $\begin{array}{r}0 \\
0.00 \\
\end{array}$ & $\begin{array}{r}0 \\
0.00 \\
\end{array}$ & $\begin{array}{r}0 \\
0.00 \\
\end{array}$ & $\begin{array}{r}1 \\
100.00 \\
\end{array}$ & 1 \\
\hline Total & 6 & 14 & 2 & 16 & 4 & 42 \\
\hline $\begin{array}{l}\text { Likelihood } \\
\text { Ratio }\end{array}$ & $\mathrm{X} 2$ & Prob $>X 2$ & & & & \\
\hline & 14.404 & 0.2757 & & & & \\
\hline \multicolumn{3}{|c|}{$\begin{array}{l}\text { Warning: } 20 \% \text { of cells have expected } \\
\text { count less than } 5 . \text { ChiSquare is suspect. } \\
\text { Warning: Average cell count less than } 5 \text {, } \\
\text { LR ChiSquare suspect. }\end{array}$} & & & & \\
\hline $\begin{array}{l}\text { Fisher's } \\
\text { Exact Test }\end{array}$ & $\begin{array}{l}\text { Two-Sided } \\
\text { Prob } \leq \mathrm{P}\end{array}$ & & & & & \\
\hline & 0.1118 & & & & & \\
\hline \multicolumn{3}{|l|}{ Bowker's Test } & & & & \\
\hline $\begin{array}{l}\text { Symmetry of } \\
\text { Disagreement }\end{array}$ & $\begin{array}{l}\text { Chi } \\
\text { Squared }\end{array}$ & Prob $>X 2$ & & & & \\
\hline & 22.33 & 0.0135 & & & & \\
\hline
\end{tabular}

A small, not statistically significant knowledge shift was reflected by the question:

"There is a risk of being told I have a tumor on my mammogram that requires further testing when there is no concern or harmful growth present" (Table 8). 31 of 42 participants responded agree/strongly agree to this statement prior to the presentation and 38 responded agree/strongly agree in post evaluation. 


\begin{tabular}{|c|c|c|c|c|c|c|}
\hline \multicolumn{7}{|c|}{$\begin{array}{l}\text { Table 8. "There is a risk of being told I have a tumor on my } \\
\text { mammogram that requires further testing when there is no concern } \\
\text { or harmful growth present." Pre-by-Post } \\
\text { Contingency Table }\end{array}$} \\
\hline $\begin{array}{l}\text { Count } \\
\text { Row \% }\end{array}$ & $\begin{array}{l}\text { Strongly } \\
\text { Agree-post }\end{array}$ & $\begin{array}{l}\text { Agree- } \\
\text { post }\end{array}$ & $\begin{array}{l}\text { No } \\
\text { Opinion- } \\
\text { post }\end{array}$ & $\begin{array}{l}\text { Disagree- } \\
\text { post }\end{array}$ & $\begin{array}{l}\text { Strongly } \\
\text { Disagree- } \\
\text { post }\end{array}$ & Total \\
\hline Strongly Agree-pre & $\begin{array}{r}1 \\
33.33 \\
\end{array}$ & $\begin{array}{r}2 \\
66.67 \\
\end{array}$ & $\begin{array}{r}0 \\
0.00\end{array}$ & $\begin{array}{r}0 \\
0.00\end{array}$ & $\begin{array}{r}0 \\
0.00 \\
\end{array}$ & 3 \\
\hline Agree-pre & $\begin{array}{r}3 \\
10.71\end{array}$ & $\begin{array}{r}24 \\
85.71\end{array}$ & $\begin{array}{r}0 \\
0.00\end{array}$ & $\begin{array}{r}1 \\
3.57\end{array}$ & $\begin{array}{r}0 \\
0.00\end{array}$ & 28 \\
\hline No Opinion-pre & $\begin{array}{r}2 \\
40.00\end{array}$ & $\begin{array}{r}1 \\
20.00\end{array}$ & $\begin{array}{r}1 \\
20.00\end{array}$ & $\begin{array}{r}1 \\
20.00\end{array}$ & $\begin{array}{r}0 \\
0.00\end{array}$ & 5 \\
\hline 5Disagree-pre & $\begin{array}{r}0 \\
0.00 \\
\end{array}$ & $\begin{array}{r}5 \\
100.00\end{array}$ & $\begin{array}{r}0 \\
0.00\end{array}$ & $\begin{array}{r}0 \\
0.00\end{array}$ & $\begin{array}{r}0 \\
0.00\end{array}$ & 5 \\
\hline $\begin{array}{l}\text { Strongly Disagree- } \\
\text { pre }\end{array}$ & $\begin{array}{r}0 \\
0.00 \\
\end{array}$ & $\begin{array}{r}0 \\
0.00 \\
\end{array}$ & $\begin{array}{r}0 \\
0.00 \\
\end{array}$ & $\begin{array}{r}0 \\
0.00 \\
\end{array}$ & $\begin{array}{r}1 \\
100.00 \\
\end{array}$ & 1 \\
\hline Total & 6 & 32 & 1 & 2 & 1 & 42 \\
\hline $\begin{array}{l}\text { Likelihood } \\
\text { Ratio }\end{array}$ & X2 & Prob $>X 2$ & & & & \\
\hline & 23.277 & 0.1065 & & & & \\
\hline \multicolumn{3}{|c|}{$\begin{array}{l}\text { Warning: } 20 \% \text { of cells have expected } \\
\text { count less than } 5 . \text { ChiSquare is suspect. } \\
\text { Warning: Average cell count less than } 5 \text {, } \\
\text { LR ChiSquare suspect. }\end{array}$} & & & & \\
\hline $\begin{array}{l}\text { Fisher's } \\
\text { Exact Test }\end{array}$ & $\begin{array}{l}\text { Two- } \\
\text { Sided } \\
\text { Prob } \leq \mathrm{P}\end{array}$ & & & & & \\
\hline & 0.0093 & & & & & \\
\hline \multicolumn{3}{|l|}{ Bowker's Test } & & & & \\
\hline $\begin{array}{l}\text { Symmetry of } \\
\text { Disagreement }\end{array}$ & $\begin{array}{l}\text { Chi } \\
\text { Squared }\end{array}$ & Prob>X2 & & & & \\
\hline & 6.87 & 0.7380 & & & & \\
\hline
\end{tabular}

For the question: "There is a risk of being told I have breast cancer and receiving treatment when there is no concern or harmful growth present," Bowker's test demonstrates (Table 9) there are only slightly significant differences in pre- and post-response. Seven people changed their response from disagree to agree post evaluation (25 disagree/strongly disagree pretest and 32 agree/strongly agree post-test). Further, 11 people who reflected no opinion prior to the educational intervention agreed there is a risk of receiving treatment when there is no concern about breast cancer after viewing the DA. This non-significant but informative change may reflect the need for enhancement of the definition of the concepts "treatment" and/or "harmful growth" in subsequent iterations of the project. 


\begin{tabular}{|c|c|c|c|c|c|c|}
\hline \multicolumn{7}{|c|}{$\begin{array}{l}\text { Table 9. "There is a risk of being told I have breast cancer and } \\
\text { receiving treatment when there is no concern or harmful growth } \\
\text { present." Pre-by-Post } \\
\text { Contingency Table }\end{array}$} \\
\hline $\begin{array}{l}\text { Count } \\
\text { Row \% }\end{array}$ & $\begin{array}{l}\text { Strongly } \\
\text { Agree-post }\end{array}$ & $\begin{array}{l}\text { Agree- } \\
\text { post }\end{array}$ & $\begin{array}{l}\text { No } \\
\text { Opinion- } \\
\text { post }\end{array}$ & $\begin{array}{l}\text { Disagree- } \\
\text { post }\end{array}$ & $\begin{array}{l}\text { Strongly } \\
\text { Disagree- } \\
\text { post }\end{array}$ & Total \\
\hline Strongly Agree-pre & $\begin{array}{r}1 \\
100.00 \\
\end{array}$ & $\begin{array}{r}0 \\
0.00 \\
\end{array}$ & $\begin{array}{r}0 \\
0.00\end{array}$ & $\begin{array}{r}0 \\
0.00 \\
\end{array}$ & $\begin{array}{r}0 \\
0.00\end{array}$ & 1 \\
\hline Agree-pre & $\begin{array}{r}1 \\
20.00 \\
\end{array}$ & $\begin{array}{r}3 \\
60.00 \\
\end{array}$ & $\begin{array}{r}0 \\
0.00 \\
\end{array}$ & $\begin{array}{r}1 \\
20.00 \\
\end{array}$ & $\begin{array}{r}0 \\
0.00 \\
\end{array}$ & 5 \\
\hline No Opinion-pre & $\begin{array}{r}1 \\
9.09\end{array}$ & $\begin{array}{r}7 \\
63.64\end{array}$ & $\begin{array}{r}2 \\
18.18\end{array}$ & $\begin{array}{r}1 \\
9.09\end{array}$ & $\begin{array}{r}0 \\
0.00\end{array}$ & 11 \\
\hline Disagree-pre & $\begin{array}{r}1 \\
5.56 \\
\end{array}$ & $\begin{array}{r}15 \\
83.33 \\
\end{array}$ & $\begin{array}{r}1 \\
5.56 \\
\end{array}$ & $\begin{array}{r}1 \\
5.56 \\
\end{array}$ & $\begin{array}{r}0 \\
0.00 \\
\end{array}$ & 18 \\
\hline $\begin{array}{l}\text { Strongly Disagree- } \\
\text { pre }\end{array}$ & $\begin{array}{r}0 \\
0.00 \\
\end{array}$ & $\begin{array}{r}3 \\
42.86 \\
\end{array}$ & $\begin{array}{r}0 \\
0.00 \\
\end{array}$ & $\begin{array}{r}1 \\
14.29 \\
\end{array}$ & $\begin{array}{r}3 \\
42.86 \\
\end{array}$ & 7 \\
\hline Total & 4 & 28 & 3 & 4 & 3 & 42 \\
\hline $\begin{array}{l}\text { Likelihood } \\
\text { Ratio } \\
\end{array}$ & $\mathrm{X} 2$ & $\begin{array}{r}\text { Prob }>X 2 \\
0.1169\end{array}$ & & & & \\
\hline \multicolumn{3}{|c|}{$\begin{array}{l}\text { Warning: } 20 \% \text { of cells have expected } \\
\text { count less than 5. ChiSquare is suspect. } \\
\text { Warning: Average cell count less than } 5, \\
\text { LR ChiSquare suspect. }\end{array}$} & & & & \\
\hline $\begin{array}{l}\text { Fisher's } \\
\text { Exact Test }\end{array}$ & $\begin{array}{l}\text { Two- } \\
\text { Sided } \\
\text { Prob } \leq \mathrm{P} \\
0.0387\end{array}$ & & & & & \\
\hline \multicolumn{3}{|l|}{ Bowker's Test } & & & & \\
\hline $\begin{array}{l}\text { Symmetry of } \\
\text { Disagreement }\end{array}$ & $\begin{array}{l}\begin{array}{l}\text { Chi } \\
\text { Squared }\end{array} \\
26.25 \\
\end{array}$ & Prob $>X 2$ & & & & \\
\hline
\end{tabular}

Generation of understanding of the value and utility of the presentation, and the impact of MPD on the screening decision were evaluated through evaluation of actual results for the questions: \# 15 (Table 10) and \#16 (Table 11). Most participants (80.94\%) reported they agree or strongly agree with the statement: “\#15. This presentation helped me to make an informed decision about breast cancer screening" (Table 10). 


\begin{tabular}{|ll|}
\hline $\begin{array}{l}\text { Table } 10 . \\
\text { “\#15 - This presentation helped me to } \\
\text { make an informed decision about breast } \\
\text { cancer screening.” }\end{array}$ \\
\hline Level of Agreement & n (\% total) \\
\hline Strongly Agree & $15(35.71 \%)$ \\
Agree & $19(45.24 \%)$ \\
Strongly Agree \& Agree & $34(80.95 \%)$ \\
No Opinion & $5(11.9 \%)$ \\
Disagree & $3(7.14 \%)$ \\
Strongly Disagree & $0(0 \%)$ \\
Total & 42 \\
\hline
\end{tabular}

Thirty-five $(83.34 \%)$ of 42 respondents reported they agree and or strongly agree with the statement "\#16. After watching this presentation, I feel better prepared to make a decision about breast cancer screening." (Table 11).

\begin{tabular}{|c|c|}
\hline \multicolumn{2}{|c|}{$\begin{array}{l}\text { Table } 11 . \\
\text { "\#16. After watching this presentation, I } \\
\text { feel better prepared to make a decision } \\
\text { about breast cancer screening." }\end{array}$} \\
\hline Level of Agreement & $\mathrm{n}(\%$ total $)$ \\
\hline Strongly Agree & $16(38.10 \%)$ \\
\hline Agree & $19(45.24 \%)$ \\
\hline Strongly Agree \& Agree & $35(83.34 \%)$ \\
\hline No Opinion & $4(9.52 \%)$ \\
\hline Disagree & $3(7.14 \%)$ \\
\hline Strongly Disagree & $0(0 \%)$ \\
\hline Total & 42 \\
\hline
\end{tabular}

Participants were invited to choose as many responses as apply to the question: “\#17. I found this presentation to be (choose ALL that apply)" (Table 12). 34 of 42 participants found the presentation to be "understandable". 32 participants reported the presentation was "helpful" to decision-making and 27 chose the descriptor "interesting." Finally, 23 reported that the presentation was "reasonable length." This was the outcome expected by the student author as it is consistent with prior publication and observations. 


\begin{tabular}{|lc|}
\hline \begin{tabular}{ll|} 
Table 12. \\
“\#17. I found this presentation to \\
be (choose as many as apply):”
\end{tabular} \\
\hline Response & $\mathrm{n}$ \\
\hline Understandable & 34 \\
Helpful & 32 \\
Interesting & 27 \\
Reasonable length & 23 \\
Too long & 6 \\
Too short & 2 \\
Too complicated for me & 1 \\
Not Helpful & 1 \\
Confusing & 0 \\
\hline
\end{tabular}

Review and categorization of presentation comments (Table 4) reflects that generally neutral observations were noted by participants. Most comments were observational about the impact of the information and its inconsistency with many commercial media presentations. The majority of comments (total $=9$ ) such as "I would like to do some fact checking" were determined to be neutral as the content of the presentation was evidence-based and well referenced within the presentation and post evaluation context in Qualtrics@. Supportive comments (total =6) were emotive and expressive. Comments such as: "Great video!" and "I wish I could see the video again" were noted. Critical comments (total $=2)$ reflected a lack of appreciation and or understanding of the content as derived from systematic review.

Over the course of initial dissemination of this project, 66 responses were recorded. Of the 66 participants, 42 completed both the pre- and post-evaluation questions provided in the survey. Only the completed, paired responses were evaluated in analysis. Contextual elements that interacted with the MPD presentation are presumed to be individual comfort and skill with the online platform and technology, prior knowledge related to the benefits and harms of BCS as well as prior belief structures based on commercially based social and political campaigns. While, comments do not reveal criticism with the technological platform, the fact that 24 participants did not progress to the post-evaluation questions causes the need to consider challenges with the technology and or dissatisfaction with the length of the presentation. 


\section{Discussion}

\section{Summary}

Analysis of the pre- and post-evaluation responses revealed that people understood the questions asked and the presentation changed their opinion about the harms and benefits of BCS. Further participants reflected enhanced preparedness for informed decision-making about BCS. The aim of the project was to pilot a clinical practice DA to provide evidence-based information about the harms and benefits of BCS. The results of data analysis demonstrate differences in preand post-test evaluation that highlight the value of provision of high-quality information in an understandable format to support women's personal preference-based decision-making about participation in BCS. It must be noted that the results of data analysis were not statistically significant due to the small sample size. However, the findings are informative about the value of an evidence-based DA in enhancement of preparedness for BCS decision-making. Further, the results provide initial feedback for improvement of the presentation and format. It is apparent that some questions contain concepts that may need to be defined further such as "harm" and "harmful growth." The definition of these concepts can be included in the instructional material and further evaluated by the pre- and posttest. Additionally, the language level of the presentation should be assessed for opportunities to reduce the literacy level to grade 7 or 8 . Alteration of the presentation content for literacy level of grade 7 or 8 would be helpful in subsequent presentation to enhance the understanding of a broader audience.

The strengths of this project include the accessibility provided by the Qualtrics format as well as visual and written presentation of evidence-based information that was previously implemented and validated by the Nordic Cochrane Center among others. The visual and auditory presentation meets the needs of both visual and auditory learners. Use of online format has been demonstrated to improve accessibility to a larger audience of learners than written, mailed format utilized by Gøtzsche et al. (2012). Ultimately, the support of value and preferencebased decision-making has been determined to be a strength by the creator and supporters of this project.

\section{Interpretation}

The impact of the MPD project on people and systems can be reflected in question \#16. "After watching this presentation, I feel better prepared to make a decision about breast cancer 
BREAST CANCER SCREENING DECISION AID

screening." (Table 10). Most participants reported enhanced preparedness for decision-making because of this presentation. A change in opinion was noted related to the question: "There is a risk of being told I have breast cancer and receiving treatment when there is no concern or harmful growth present." This demonstrates a shift in belief structure that was informed by the presentation. The reality that treatment is provided to women who do not have breast cancer was clearly previously not opined by participants. Further, most women reported MPD was understandable, helpful, interesting and reasonable length.

The previously established role of an evidence-based DA in support of value and preference-based decision-making is consistent with the findings of this project. The individual value of MPD, change in opinion based on exposure to the MPD presentation as well as corresponding helpfulness in decision-making, has been demonstrated.

\section{Limitations}

This quality improvement project had several limitations in implementation. The small sample size achieved prior to the need for results analysis was unfortunate as responses from 100 or more women would have been preferred. Further, solicitation of the convenience sample via social media could have biased the participants toward support of the author/student. The participants' desire to support the student/author's efforts in completion of her education could influence the responses. The manner of this influence is unknown. Future measures could be implemented to control for awareness of the participant about the personal identity of the author of the presentation. However, this would remove the ability to provide contact in the event further comments and or support were desired by participants. Comments provided by participants in question "\#18. As this project aims to improve the provision of evidence-based information to the community, please feel free to share any additional comments and or suggestions in the space below." (Table 4) subjectively related the individual value of the observations by the participants and provide feedback about some of the concerns and or limitations as perceived by participants.

Within hours of posting (after 6 participants had completed the presentation), an initial observation was made that the link to Qualtrics® could be separated from the posting in social media. This prompted relocation of the instructions to the first question of the Qualtrics ${ }^{\circledR}$ link. Therefore, the potential exists that the first 6 participants did not receive the same instruction as 
BREAST CANCER SCREENING DECISION AID

the remaining participants. Further, the reference list was initially included in the video presentation but was replicated, based on feedback, in the conclusion (thank you page) of the Qualtrics® survey after 20 participants were recorded.

Finally, the readability of the content factored by the Flesh-Kincaid tool at the $11^{\text {th }}$ grade level and at similar levels with other tools (Gunning Fog; Coleman-Liau; Smog Index). This was partially attributed to the words overdiagnosis, overtreatment, evidence-based presentation, and examination. While these words were carefully defined within the presentation, their use could be re-evaluated and altered to reduce the readability of the dialogue to $7^{\text {th }}-8^{\text {th }}$ grade level in the future if desired. However, consideration would need to be provided for the variation in application from the original terms used in the Gøtzsche et al. (2012) leaflet on which MPD was based. Generalizability of this project to other community settings is limited by the $11^{\text {th }}$ grade readability level of the presentation. Consideration for implementation in other settings should consider adjustment of the readability to suit the educational level of the audience.

As previously noted, post presentation responses were not recorded for 24 participants. Consideration of the potential of individual disinterest, technological challenges and or problems with the Qualtrics ${ }^{\circledR}$ platform and potential loss of data must be investigated before use of this platform in the future. At the date of publication of this report, no explanation for the missing data was available beyond the presumption that individual participants voluntarily provided preevaluation responses but closed out of the presentation at some point prior the completion of the video and post-evaluation questions. The impact of this limitation resulted in a smaller than desired sample size and should be addressed in future iterations of the project to prevent loss of evaluation data.

The HealthyUNH pause in dissemination, due to concerns expressed about potential perception of financial support, contributed to reduction in participant responses available at the time of data assimilation. Due to the timeline imposed by DNP studies, data analysis was initiated on 4-1-18. However, the perceived value of the tool by HealthyUNH and the UNH community was determined and dissemination was continued as planned and started after compilation of this report on 4-8-18.

One entry from the initial reported as posted on 4-8-18 was deleted due to comment in the final note field that stated: "testing only- remove this entry- it can't count in your data." Consult with faculty agreed that this was likely the response of another department faculty 
BREAST CANCER SCREENING DECISION AID

member who performed an unsolicited "test" of the survey. One benefit of use of the Qualtrics platform is the ability to force response to each question before progressing through the presentation. Superficially, this is helpful to information gathering. However, the chance that an undesired answer is provided to progress the presentation must be acknowledged. No further missing data or data requiring elimination was noted.

\section{Conclusions}

Overall, this project demonstrates that providing evidence-based information directly to women outside of a clinical consultation may be acceptable, informative, and perceived as valuable in the BCS decision-making process. These findings are important as understanding of evidence-based information is a fundamental element in the empowerment of the decision maker with the goal of informed decision-making.

Evaluation feedback from the participants before and after use of the tool demonstrated that MPD was helpful and enhanced preparedness for BCS decision-making.

The usefulness of the MPD tool can be incorporated into the SDM process in the clinical setting. However, it has demonstrated utility as a tool for individual use outside of the clinical encounter. The HealthyUNH program is committed to enhancing the use of shared decision-making across many healthcare decisions for the community at UNH. Projects like this one, that provide evidence-based information directly to community members about a healthcare decision, can be provided to improve the content of evidence-based information available in the community, and support individual informed (and shared) decision-making across many healthcare decisions. This presentation will be sustained by the HealthyUNH program for the upcoming 3-4 months. The Qualtrics link will continue to be sponsored by the HealthyUNH program staff with access to the MPD presentation and pre- and post-presentation questions. Ongoing evaluation of the appropriateness of continuation of the MPD presentation and potential revisions will be at the discretion of the HealthyUNH program.

The implications for practice and for further study include the utilization of similar evidence-based presentations to the community about screening decisions beyond BCS. These may include evidence about screening for prostate cancer with prostate-specific antigen (PSA) and/or for cervical cancer with Papanicolaou (Pap) and human papillomavirus (HPV) testing among others. Based on the recognition that screening tests have harms as well as benefits, the 
BREAST CANCER SCREENING DECISION AID

USPSTF has taken initiative to advocate for the use of informed and shared decision-making for support of screening decisions. Presentations such as MPD serve to disseminate accurate, evidence-based information to support value and preference-based decisions across these topics as identified by the USPSTF. Adoption of evidence-based presentations that educate the decision maker about the harms and benefits in actual risk terms would assist the empowerment of the individual towards more individualized screening decision-making. Through performance of value and preference-based decisions, the individual is able to comprehend and integrate the consequences of the decision and choose actions consistent with discrete values and preferences.

\section{Funding}

This quality improvement project was funding by the primary author as a component of the requirements of the Doctor of Nursing Practice program at UNH. Resources, including software JMP® and Microsoft Office 365®, were allocated through tuition fees as resources available to all graduate students by UNH. Time and effort by faculty advisor Dr. Gene Harkless was reimbursed through workload credit and salary adjustment in accord with contractual agreements with the DNP program. HealthyUNH program support was facilitated by Jo Porter, Director for the Institute for Health Policy and Practice as well as the HealthyUNH program. No further funding was required or provided. 


\section{References}

American College of Radiology (ACR) \& Society of Breast Imaging (SBI). (2016). Press

Release: USPSTF Breast Cancer Screening Recommendations Could Endanger Women.

Retrieved from: https://www.acr.org/About-Us/Media-Center/Press-Releases/2016-Press-

Releases/20160111-USPSTF-Breast-Cancer-Screening-Recommendations-Could-

Endanger-Women.

Agency for Healthcare Research and Quality (AHRQ). (2017). U.S. Preventive Services Task

Force (USPSTF): An Introduction. Accessed at:

https://www.ahrq.gov/professionals/clinicians-providers/guidelinesrecommendations/uspstf/index.html.

American Cancer Society (ACS). (2016). American Cancer Society Recommendations for the

Early Detection of Breast Cancer. Retrieved from: https://www.cancer.org/cancer/breastcancer/screening-tests-and-early-detection/american-cancer-society-recommendationsfor-the-early-detection-of-breast-cancer.html.

American Cancer Society (ACS). (2017). History of ACS Recommendations for the Early

Detection of Cancer in People Without Symptoms. Accessed at:

https://www.cancer.org/healthy/find-cancer-early/cancer-screeningguidelines/chronological-history-of-acs-recommendations.html.

American Congress of Obstetricians and Gynecologists. (2016). Practice Advisory: Breast

Cancer Screening. Retrieved from: https://www.acog.org/About-ACOG/News-

$\underline{\text { Room/Practice-Advisories/Practice-Advisory-Breast-Cancer-Screening. }}$

American Congress of Obstetricians and Gynecologists. (2017). Practice Advisory: Breast

Cancer Screening. Retrieved from: https://www.acog.org/Clinical-Guidance-and-

$\underline{\text { Publications/Practice-Bulletins/Committee-on-Practice-Bulletins-Gynecology/Breast- }}$

Cancer-Risk-Assessment-and-Screening-in-Average-Risk-Women.

American College of Radiology, ACR Appropriateness Criteria®: Breast Cancer Screening.

(2016). Retrieved from: https://acsearch.acr.org/docs/70910/Narrative/

Andersson, I., Aspegren, K., Janzon, L., Landberg, T., Lindholm, K., Linell, F., \& ... Sigfússon, B. (1988). Mammographic screening and mortality from breast cancer: the Malmö mammographic screening trial. BMJ (Clinical Research Ed.), 1988297(6654), 943-948.

Bodemer, N \& Gaissmaier, W (2012) in: Risk Communication in Health. In Roeser S et al. 
BREAST CANCER SCREENING DECISION AID

(Eds), Handbook of risk theory: Epistemology, Decision Theory, Ethics, and Social Implications of Risk. (pp. 621-660). Dordrecht [u.a.] : Springer, 2012.

Bourmaud, A., Soler-Michel, P., Oriol, M., Regnier, V., Tinquaut, F., Nourissat, A., \& ... Chauvin, F. (2016). Decision aid on breast cancer screening reduces attendance rate:

Results of a large-scale, randomized, controlled study by the DECIDEO group. Oncotarget, 7(11), 12885-12892.

Dartmouth Atlas Project. (2007). Preference-Sensitive Care. Accessed at: http://www.dartmouthatlas.org/downloads/reports/preference_sensitive.pdf

Eccles, J. (1983). Expectancies, values, and academic behaviors. In J. T. Spence (Ed.), Achievement and achievement motives: Psychological and sociological approaches (pp. 75-146). San Francisco, CA: W. H. Freeman.

Elkin, E. B., Pocus, V. H., Mushlin, A. I., Cigler, T., Atoria, C. L., \& Polaneczky, M. M. (2017). Facilitating informed decisions about breast cancer screening: development and evaluation of a web-based decision aid for women in their 40s. BMC Medical Informatics \& Decision-making, 171-9. doi:10.1186/s12911-017-0423-7.

Elwyn G, O’Connor A, Stacey D, et al. (2006). International Patient Decision Aids Standards (IPDAS) Collaboration. Developing a quality criteria framework for patient decision aids: online international Delphi consensus process. BMJ. 333(7565):417.

Gøtzsche, P.C., Hartling, O.J., Nielsen, M., Brodersen, J. (2012) "Screening for breast cancer with mammography." Accessed at: http://nordic.cochrane.org/screening-breast-cancermammography.

Gøtzsche, P.C. \& Jorgensen, K.J. (2013). Screening for breast cancer with mammography (Review). Cochrane Database Of Systematic Reviews, (6), doi: 10.1002/14651858.CD001877.pub5

Gøtzsche, P. C. (April 1, 2015). Video interview with John McDougall. Available at: https://www.youtube.com/watch?v=paCAc9p_GsQ.

Gummersbach, E., in der Schmitten, J., Mortsiefer, A., Abholz, H., Wegscheider, K., \& Pentzek, M. (2015). Willingness to participate in mammography screening: a randomized controlled questionnaire study of responses to two patient information leaflets with different factual content. Deutsches Arzteblatt International, 2015112(5), 61-68.

Gunn, C. M., Soley-Bori, M., Battaglia, T. A., Cabral, H., \& Kazis, L. (2015). Shared Decision 
BREAST CANCER SCREENING DECISION AID

Making and the Use of Screening Mammography in Women Younger Than 50 Years of Age. Journal Of Health Communication, 20(9), 1060-1066.

doi:10.1080/10810730.2015.1018628.

Hersch J., Barratt, A., Jansen, J., Irwig, L., McGeechan, K., Jacklyn, G., \& ...

McCaffery, K. (2015). Use of a decision aid including information on overdetection to support informed choice about breast cancer screening: a randomised controlled trial. Lancet (London, England), 385(9978), 1642-1652.

Health Insurance Portability and Accountability Act of 1996. PUBLIC LAW 104-191. Retrieved from: https://www.gpo.gov/fdsys/pkg/PLAW-104publ191/pdf/PLAW104publ191.pdf

Houssami, N., \& Miglioretti, D. L. (2016). Breast Cancer Screening: An Examination of Scientific Evidence. Elsevier Inc.

Kösters, J. P., \& Gøtzsche, P. C. (2003). Regular self-examination or clinical examination for early detection of breast cancer. The Cochrane Database Of Systematic Reviews, (2), CD003373.

Henriksen, M. V., Guassora, A. D., \& Brodersen, J. (2015). Preconceptions influence women's perceptions of information on breast cancer screening: a qualitative study. BMC Research Notes, 8(1), 1-9. doi:10.1186/s13104-015-1327-1

Jørgensen, K. J., Gøtzsche, P. C., Kalager, M., \& Zahl, P. (2017). Breast Cancer Screening in Denmark: A Cohort Study of Tumor Size and Overdiagnosis. Annals Of Internal Medicine, 166(5), 313-323. doi:10.7326/M16-0270.

Lerner, B. H. (2003). 'To See Today with the Eyes of Tomorrow': A History of Screening Mammography. CANADIAN BULLETIN OF MEDICAL HISTORY, (2). 299.

Løberg, M., Lousdal, M. L., Bretthauer, M., \& Kalager, M. (2015). Benefits and harms of mammography screening. Breast Cancer Research: BCR, 1763. doi:10.1186/s13058-0150525-z.

Mathieu, E., Barratt, A. L., McGeechan, K., Davey, H. M., Howard, K., \& Houssami, N. (2010). Helping women make choices about mammography screening: An online randomized trial of a decision aid for 40-year-old women. Patient Education and Counseling, 81(1). 
BREAST CANCER SCREENING DECISION AID

Marmot, M. G., Altman, D. G., Cameron, D. A., Dewar, J. A., Thompson, S. G., \& Wilcox, M. (2013). The benefits and harms of breast cancer screening: an independent review. British Journal Of Cancer, 108(11), 2205-2240. doi:10.1038/bjc.2013.177.

Miller, A., Wall, C., Baines, C., Sun, P., To, T., \& Narod, S. (2014). Twenty-five-year follow-up for breast cancer incidence and mortality of the Canadian National Breast Screening Study: randomised screening trial. BMJ (Clinical Research Ed.), 348g366.

National Comprehensive Cancer Network (NCCN). (2017). Breast Cancer Screening and Diagnosis. Retrieved from: https://www.nccn.org/professionals/physician_gls/pdf/breastscreening.pdf

National Institute for Health (NIH). (1997). Breast Cancer Screening for Women Ages 40-49: National Institutes of Health Consensus Development Conference Statement. Accessed at: https://consensus.nih.gov/1997/1997BreastCancerScreening103html.htm.

O'Connor, A. M., Llewellyn-Thomas, H. A., \& Flood, A. B. (2004). Modifying Unwarranted Variations in Health Care: Shared Decision-making Using Patient Decision Aids. Health Affairs, 2363-72. doi:10.1377/hlthaff.var.63.

Oeffinger K.C., Fontham E.T., Etzioni R, Herzig A, Michaelson J.S., Shih Y.C. et al. (2015). American Cancer Society. Breast Cancer Screening for Women at Average Risk: 2015 Guideline Update from the American Cancer Society. JAMA. 314(15):1599-614. doi: 10.1001/jama.2015.12783.

Pace, L. E., \& Keating, N. L. (2014). A systematic assessment of benefits and risks to guide breast cancer screening decisions. JAMA: Journal Of The American Medical Association, 311(13), 1327-1335. doi:10.1001/jama.2014.1398.

Picard, J. D. (1998). [History of mammography]. Bulletin De L'academie Nationale De Medecine, 182(8), 1613-1620.

Rifkin, E. Lazris, A. (2015). Interpreting Health Benefits and Risks: A Practical Guide to Facilitate Doctor-Patient Communication. New York, New York: Springer International Publishing.

SAS Institute Inc. (2017). JMP Statistical Discovery from SAS. Retrieved from: https://www.jmp.com/en_us/software.html.

Saver, B. G., Mazor, K. M., Luckmann, R., Cutrona, S. L., Hayes, M., Gorodetsky, T., \& Bacigalupe, G. (2017). Persuasive Interventions for Controversial Cancer Screening 
BREAST CANCER SCREENING DECISION AID

Recommendations: Testing a Novel Approach to Help Patients Make Evidence-Based

Decisions. Annals Of Family Medicine, 15(1), 48-55. doi:10.1370/afm.1996.

Schapira, M., Hubbard, R., Seitz, H., Conant, E., Schnall, M., Capella, J., \&

Armstrong, K. (2016). A randomized controlled trial of a risk based mammography screening decision aid for women 39-48 years of age. Journal of General Internal Medicine, 31(2 SUPPL. 1), S105.

Shapiro, S., \& Health Insurance Plan of Greater New, Y. (1988). Periodic screening for breast

: The Health Insurance Plan project and its sequelae, 1963-1986. United States of America: Johns Hopkins Univ. Press.

Siu AL (2016). Screening for breast cancer: U.S. Preventive Services Task Force recommendation statement. Annals of Internal Medicine.164(4):279.

Stacey, D., Légaré, F., Col, N. F., Bennett, C. L., Barry, M. J., Eden, K. B., \& Wu, J. C. (2014). Decision aids for people facing health treatment or screening decisions. The Cochrane Database of Systematic Reviews, (1), CD001431. doi:10.1002/14651858.CD001431.pub4.

Stacey, D., Légaré, F., Col, N. F., Bennett, C. L., Barry, M., Eden, K. B., \& Wu, J. C. (2017). Decision aids for people facing health treatment or screening decisions. Clinical Orthopaedics \& Related Research, 475(5), 1301-1304. doi:10.1002/14651858.CD001431.pub4.

Thomas, D., Gao, D., Ray, R., Wang, W., Allison, C., Chen, F., et al. (2002). Randomized trial of breast self-examination in Shanghai: final results. Journal Of The National Cancer Institute, 94(19), 1445-1457.

US Food \& Drug Administration. (2017). Mammography Quality Standards Act and Program.

Accessed at: https://www.fda.gov/RadiationEmittingProducts/MammographyQualityStandardsActandProgram/

U.S. Preventive Services Task Force (USPSTF). (2002). Screening for breast cancer:

Recommendations and rationale. Annals of Internal Medicine; Philadelphia 137:5: 344-6.

U.S. Preventive Services Task Force (USPSTF). (2009). Screening for breast cancer: U.S.

Preventive Services Task Force recommendation statement. Ann Intern Med. 151(10):716-26, W-236. doi: 10.7326/0003-4819-151-10-200911170-00008.

van Agt, H. M., Korfage, I. J., \& Essink-Bot, M. (2014). Interventions to enhance informed 
BREAST CANCER SCREENING DECISION AID

choices among invitees of screening programmes - a systematic review. European Journal Of Public Health, 24(5), 789-801. doi:10.1093/eurpub/ckt205.

Welch, H. (2009). Overdiagnosis and mammography screening. BMJ: British Medical Journal (Overseas \& Retired Doctors Edition), 339(7714), b1425.

Welch, H. G., Prorok, P. C., O'Malley, A. J., \& Kramer, B. S. (2016). Breast-cancer tumor size, overdiagnosis, and mammography screening effectiveness. New England Journal Of Medicine, 375(15), 1438-1447. doi:10.1056/NEJMoa1600249.

Yi, H., Xiao, T., Thomas, P. S., Aguirre, A. N., Smalletz, C., Dimond, J., \& Kukafka, R. (2015). Barriers and Facilitators to Patient-Provider Communication When Discussing Breast Cancer Risk to Aid in the Development of Decision Support Tools. AMIA. Annual Symposium Proceedings. AMIA Symposium, 20151352-1360. 


\title{
Appendix \\ Appendix A: Presentation format with pre and post evaluation questions by number as presented in Qualtrics $\AA^{\mathrm{U}} \mathrm{UNH}$.
}

\author{
1. Welcome! \\ Estimated total time to completion about 12 minutes \\ Thank you! \\ Kimberly C. Gibbons, MS, RN, CNM, CNL \\ Doctor of Nursing Practice Student \\ University of New Hampshire \\ Kimberly.gibbons@unh.edu
}

I am asking women between 40 and 69, at average risk for breast cancer, to participate in this quality improvement project that seeks feedback on an evidence-based educational program about breast cancer screening.

This project asks you to answer a few short questions, watch an evidence-based presentation about the benefits and harms of breast cancer screening, and provide me feedback about your experience.

The presentation link is confidential and does not track identifying user information.

*Based on: Gøtzsche, P.C., \& Jørgensen, K.J. (2013). Screening for breast cancer with mammography. Cochrane Database of Systematic Reviews, 6(CD001877). DOI: 10.1002/14651858.CD001877.pub5.

Full reference list available upon request from Kimberly.gibbons@unh.edu

2. How old are you? Please type in your age. This is confidential.

3. I know that I am at higher risk for developing breast cancer. I have been diagnosed with breast cancer and or I have a first-degree relative with breast cancer (mother or sister) and or I know I have genetic or other factors that put me at high risk for development of breast cancer.

True - False

4. There are more benefits than harms related to breast cancer screening (mammography).

Strongly Agree - Agree - No opinion - Disagree - Strongly Disagree

5. There are more harms than benefits related to breast cancer screening (mammography).

Strongly Agree - Agree - No opinion - Disagree - Strongly Disagree

6. There is a risk of being told I have a tumor on my mammogram that requires further testing when there is no concern or harmful growth present.

Strongly Agree - Agree - No opinion - Disagree - Strongly Disagree

7. There is a risk of being told I have breast cancer and receiving treatment when there is no concern or harmful growth present. Strongly Agree - Agree - No opinion - Disagree - Strongly Disagree

8. The best age to begin to have annual (every year) mammograms is: $35-40-45-50-55-60-65-$ Never

9. $<<$ PRESENTATION>>

Link available: https://www.youtube.com/edit?o=U\&video id=ADF54UNurLA

10. <This question records and manages how long a participant spends on this page. This question is not displayed to the participant.>

11. There are more benefits than harms related to breast cancer screening (mammography).

Strongly Agree - Agree - No opinion - Disagree - Strongly Disagree

12. There are more harms than benefits related to breast cancer screening (mammography).

Strongly Agree - Agree - No opinion - Disagree - Strongly Disagree

13. There is a risk of being told I have a tumor on my mammogram that requires further testing when there is no concern or harmful growth present.

Strongly Agree - Agree - No opinion - Disagree - Strongly Disagree

14. There is a risk of being told I have breast cancer and receiving treatment when there is no concern or harmful growth present. Strongly Agree - Agree - No opinion - Disagree - Strongly Disagree

15. This presentation helped me to make an informed decision about breast cancer screening.

Strongly Agree - Agree - No opinion - Disagree - Strongly Disagree 
BREAST CANCER SCREENING DECISION AID

16. After watching this presentation, I feel better prepared to make a decision about breast cancer screening.

Strongly Agree - Agree - No opinion - Disagree - Strongly Disagree

17. I found this presentation to be (choose ALL that apply):

Understandable

Too complicated for me

Reasonable length

Too long

Too short

Interesting

Confusing

Helpful

Not helpful

18. As this project aims to improve the provision of evidence-based information to the community, please feel free to share any additional comments and or suggestions in the space below. Thank you! (free text response)

19. Thank you!

Your input is appreciated and we hope you are better prepared to move forward with

Your Personal Decision!

References

${ }^{*}$ Breast Cancer Action. (2017). Should I get a mammogram? Retrieved from: www.bcaction.org

*Gøtzsche, P.C., \& Jørgensen, K.J. (2013). Screening for breast cancer with mammography. Cochrane Database of Systematic Reviews, 6(CD001877). DOI: 10.1002/14651858.CD001877.pub5.

*Gøtzsche, P.C., Hartling, O.J., Nielsen, M., Brodersen, J. (2012) "Screening for breast cancer with mammography." Accessed at: http://nordic.cochrane.org/screening-breast-cancer-mammography.

${ }^{*}$ Miller, A.B., Wall, C., Baines, C.J., Sun, P., To, T. and Narod, S.A. (2014). Twenty five year follow-up for breast cancer incidence and mortality of the Canadian National Breast Screening Study: randomized screening trial. BMJ, 348(g366).

*Practice Bulletin No. 179 Summary: Breast Cancer Risk Assessment and Screening in Average-Risk Women. (2017). Obstetrics And Gynecology, 130(1), 241-243. doi:10.1097/AOG.0000000000002151.

*Siu, A. L. (2016). Screening for Breast Cancer: U.S. Preventive Services Task Force Recommendation Statement. Annals Of Internal Medicine, 164(4), 279-296. doi:10.7326/M15-2886

*Winch, C. J., Sherman, K. A., \& Boyages, J. (2015). Toward the breast screening balance sheet: cumulative risk of false positives for annual versus biennial mammograms commencing at age 40 or 50. Breast Cancer Research and Treatment, (1). 211. 